\title{
学術・技術論文
}

\section{重心の実行可能領域を利用した粗密段階計算に基づく軌道計画法 によるヒューマノイドロボットのはしご昇降と乗り移り動作の実現}

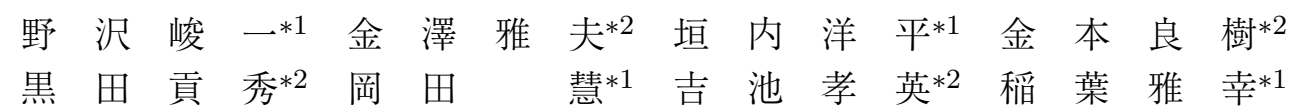

\section{Coarse-to-fine Humanoid Motion Planning Using COM Feasible Region and Achievement of Humanoids Ladder Climbing and Transition}

\author{
Shunichi Nozawa*1, Masao Kanazawa*2, Yohei Kakiuchi*1, Yoshiki Kanemoto*2,

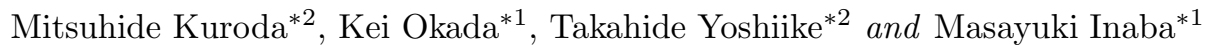

\begin{abstract}
Trajectory planning for humanoid robots requires satisfying various constraints such as balance, contact, joint limitation, kinematics, and collision. To obtain trajectory efficiently, related research has integrated coarse motion planning to fine full-body trajectory generation. In this paper, we propose a humanoid motion planner satisfying various constraints based on key pose generation by exploiting center-of-mass (COM) feasible region (CFR): (a) We show a method to project approximately balance constraints of statics and dynamics into CFR. (b) We propose a key pose generation capable of considering swing and support phase to satisfy asymptotically CFR constraint while satisfying kinematics constraints. (c) We show a method to obtain full-body trajectory by interpolating obtained key pose. We validate our proposed method through evaluations, in which the robot performs locomotion tasks related to ladder climbing under the stringent constraints, and experiments, in which the real robot achieves ladder motion.
\end{abstract}

Key Words: Humanoid Robot, Motion Plannning, Three-dimensional Locomotion

\section{1. 序論}

近年，工場・電力施設など人間を対象としたインフラの検査・ 維持管理のため，環境中を移動可能なヒューマノイドロボット が期待されている. 同じく近年，複数の研究チームがヒューマ ノイド・脚型ロボットによる段ばしご・垂直はしご上り動作を 実現している [1]〜 [5]. 傾斜の厳しい垂直はしご昇降動作やはし ごとキャットウォーク間の乗り移り動作（Fig. 1）はインフラ 内移動に必須であり，特に後者はこれまで等身大ヒューマノイ ド・脚型ロボット実機で実現されていない。ヒューマノイドロ ボットでこれらの動作を実現するには，関節可動域限界，トル ク限界，三次元的な転倒抢よび滑りのないバランス維持，リン ク間干渉回避など多様な制約を同時に満たし，軌道計画する必 要がある。

軌道生成法として，これらの制約条件をすべて関節角・トルク

原稿受付 2017 年 1 月 21 日

${ }^{* 1}$ 東京大学大学院情報理工学系研究科

$* 2$ 本田技術研究所 基礎技術研究センター

${ }^{* 1}$ Graduate School of Information Science and Technology, The University of Tokyo

${ }^{* 2}$ Fundamental Research Center, Honda R \& D Co., Ltd.

口本論文は新規性（要素分野）で評価されました。

口J-STAGE では本論文の電子付録として動画が閲覧できます。
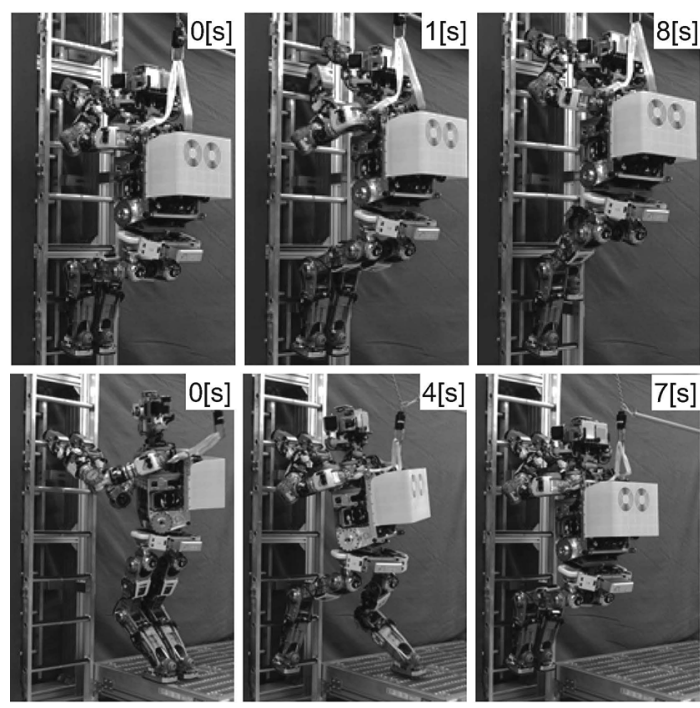

Fig. 1 Achievment of vertical ladder climbing and transition. The distance between rungs is $0.27[\mathrm{~m}]$ and width is $0.4[\mathrm{~m}]$

軌道レベルで考慮し軌道計画を行う方法が挙げられ [6] [7], 制約 を有効に利用した実行可能解を得られる特徵があるが, 計算量 が多くオンライン生成することが難しい。これに対し，以下の 2 点を考慮することで効率的に計算することが期待できる. (a) 

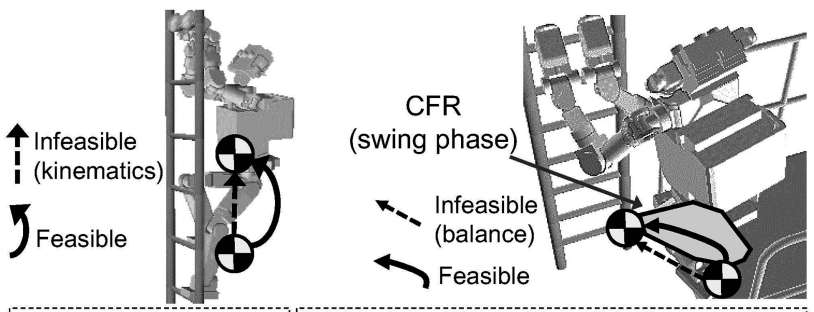

(a) Vertical Climbing (b) Ladder Transition (bird's eye view)

Fig. 2 Stringent constraints during swing and support phase infeasible and feasible COM interpolation

重心質点系のような低次元化モデルを部分的に活用する，(b) ま ず時間的に粗く制約を考慮し運動計算を行い，補間などにより 時間的に密な軌道を得るといった段階的な計算を行う。本稿で は, (b) を粗密段階計算, 粗な間引いた時刻列をキーフレーム, キーフレームでの運動情報をキーポーズとよぶ.

上記のような粗密段階計算によりはしご昇降のような運動を 実現するためには，キーフレームの選び方，補間方法が大きな 課題となる. Fig. 2 に二つの支持脚期間の重心を補間する例を 示す. Fig. 2 (a) に扔いて破線の補間を行うと, 関節可動域制限, 脚伸びきりなどの要因により実行不可能となる. Fig. 2 (b)に抒 いて破線の補間を行うと, 多点接触により形状が複雑となった 実行可能な領域 (黒縁死色) から遊脚期の重心軌道が逸脱し実行 不可能となる. この領域を, 本稿では重心実行可能領域 (COM Feasible Region, CFR）とよぶ.いずれのケースにおいても, 遊脚期の運動学制約, バランス制約を考慮する実線の補間が有 効であると考えられる。こういった遊脚期・支持脚期双方の制 約を効率よく考慮することは，まだ重要な技術的課題である。

これらを踏まえ本稿では, 重心実行可能領域を利用した粗密 段階計算に基づくヒューマノイドロボットの軌道計画法を提案 する. 提案手法は次のような特徴を持つ. (a) 静力学・動力学 の双方を利用可能な, バランス制約の重心実行可能領域への射 影方法を提供する. (b) 遊脚期・支持脚期双方のキーフレーム で, ロボット重心位置が重心実行可能領域に内包され, 領域境 界から極力遠ざかるように逆運動学計算を解くことで, 運動学 制約・バランス制約を満たす粗なキーポーズを得る（c）キー ポーズ列から重心軌道補間などを行い, 最終的に密な軌道計算 を行う. 本稿では, 多様でかつ厳しい制約が課される, 等身大 ヒューマノイドロボットによるはしご昇降動作などに提案手法 を適用し評価する。また，センサフィードバック制御[8] を伴い 実機で計画軌道を再生し，これまで実現例が少ない垂直はしご 昇降㧍よび実現例がない乗り移り動作が実機で実現できること を示す. 以下, 第 2 章では提案手法概要について, 第 4 章〜第 5 章で軌道計画法について. 第 6 章では, 軌道計画法の評価お よび実験結果について述べる.

\section{2. 重心実行可能領域を利用する軌道計画法}

本章では考慮する制約と提案手法概要について説明する.

\section{1 多種制約条件下での軌道計画とマージン}

ヒューマノイドロボットの三次元的運動軌道生成には以下の ような多様な制約を満たす必要がある。

（C1）干渉回避制約（ロボットー環境間干渉および自己干渉）
（C2）脚腕などの可到達範囲制約

（C3）関節可動域および関節速度上下限制約

（C4）三次元バランス制約（力学平衡および各接触部位での接 触制約)

（C5）関節トルク上下限制約

上記の $\mathrm{C} 1 ， \mathrm{C} 3 \sim 5$ は，制約条件の線形近似なども含めるこ とにより線形不等式制約として扱う。一方 C2 はヒューマノイ ドロボットのような多自由度ロボットの場合, 解析的に逆運動 学解や可到達範囲を得ることが困難であるため, 逐次的な逆運 動学演算の可解性を用いて考慮する. 以降で単に運動学制約と 述べた場合は $\mathrm{C} 1 \sim 3$ を指すものとする.

本稿ではさらにキーポーズ生成時にこれら制約からの余裕の あるロバストな解を得るマージンとして，ハードマージン・ソ フトマージンを導入する。 ハードマージンは不等式制約などの 境界を狭めることとする，例えば，関節可動域を減らす，接触 制約の摩擦係数を減らすことなどを指す。ソフトマージンは最 適化計算などで不等式制約の境界から逸脱している量を最小化 することとする.

\section{2 軌道計画・再生法概要}

以下では提案する軌道計画法の概要および実機での軌道再生 法について述べる. 本稿では, 軌道は毎制御周期ごとの動作デー 夕列を指し，キーフレームは間引いた時刻列とする，キーポー ズはキーフレームでの関節角度, 腰位置姿勢, 重心位置, 接触 力和（Contact Wrench Sum, CWS [9]）を含む運動情報とす る. 提案する軌道計画は, 最終目標エンドエフェク夕着地位置, 歩容形態情報（クロール，ペースなど）を入力とし, 最終的に 関節角・腰位置姿勢・接触レンチ・トルク軌道を生成する。計 画軌道は安定化制御系へ目標值として入力され，センサフィー ドバック制御を伴い実機で再生される.さらに，ロボットの基 底リンクを単に腰と表記する。

軌道生成制御の手順は Fig. 3 および以下になる。下記の Stage 0 4 が軌道計画法の工程, Stage5 は実機での軌道再生 法に相当する。軌道計画法は, キーポーズ生成（Stage2）を含 む粗密段階計算を採用しており，その中でバランス制約を重心 実行可能領域に射影し, 実行可能でかつ制約境界から余裕のあ るロバストな解を得る点が特徴である。

Stage0 エンドエフェクタ着地位置列計算: 環境・ロボット情報に 基づき， 2 足歩行やはしご昇降など移動夕スクに応じた方 法で, 最終目標位置までのエンドエフェクタ着地位置列 と歩容形態情報に基づいた着地の順序を自動計画する.

Stage1 エンドエフェクタ軌道補間：環境と干渉なく滑らかに エンドエフェクタ着地位置間をつなぐ軌道の補間を行 う。この補間方法にはスプライン補間と躍度最小補間 を併用している.

Stage 2 多様な制約を考慮するキーポーズ生成（第 3 章，第 4 章)：各キーフレームで $\mathrm{C} 1 \sim 4$ の制約条件を考慮しキー ポーズを計算する。 キーフレームは遊脚期・支持脚期 双方にサンプルし, バランス制約 C4 は重心実行可能 領域に射影して活用する。 これら C1，C3，C4 はハー ドマージン抢よびソフトマージンを用いて, 後の計算 工程より厳しい条件下で運動生成を行う。 


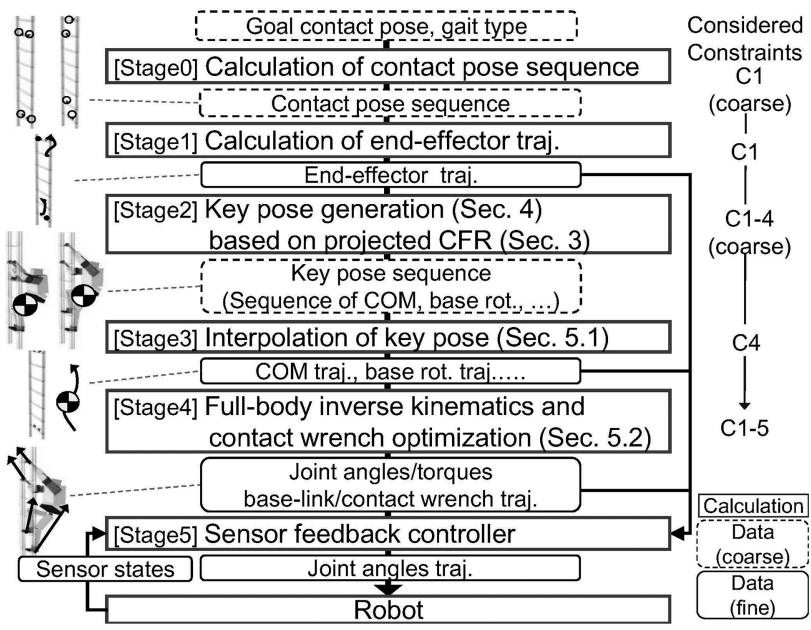

Fig. 3 Configuration of proposed system. Calculation (rectangles) and data (rounded rectangles)

Stage 3 キーポーズに基づく重心・腰姿勢・関節角補間（第 5 章)：各キーポーズを補間し，重心・腰姿勢・関節角軌 道生成を行う。特に重心軌道補間に重心系モデルを利 用し，C4 の接触制約を考慮する。

Stage4 瞬時全身運動計算 (第 5 章): 瞬時の全身運動計算として, 瞬時全身逆運動学・接触レンチ最適化を行う. Stage 3 ま でで得られる各時刻の瞬時エンドエフェク夕位置姿勢・ 重心位置・腰姿勢に基づき, 瞬時関節角・腰位置姿勢・ 接触レンチ・トルク計算を行い, 最終的な運動軌道を 求める. 瞬時全身運動計算では C1〜 5すべてを考慮し, ハード・ソフトマージンは特に考慮しないか，もしく はキーフレーム運動生成時から緩和したものを用いる. Stage5 センサフィードバックに基づく安定化制御：軌道の実 機再生時にセンサフィードバックに基づき関節軌道を 修正し，ロボットの関節位置サーボ系へ関節角指令を 送り動作の実行・安定化を図る。

\section{3 関連研究と提案手法との比較}

以下では関連研究と比較した提案手法の位置づけを述べる.

\section{3 .1 バランス制約判定・射影手法}

ロボットが物体・環境と多点で接触する条件下でのバランス制 約の判定方法, 射影方法などは, 従来より把持研究の分野（例 えば文献 [10]）で議論されている。これに加え脚型ロボットの 従来研究では，多点で環境と接触する条件下での重心などに関 する運動に着目し, バランス制約の効率的な判定方法, 射影方 法などが提案されている. 動力学を考慮した射影・低次元化モ デルとしては, 六次元の CWS [9], 三次元の慣性力や重心加速 度 [11] [13], 摩擦を考慮しない一般化 ZMP [14], 摩擦も考慮 可能な ZMP [15] [16] への射影や，ZMP の可操作だ円体の利 用 [17] などが提案されている. 動力学を考慮する射影方法の多 くは，重心位置と慣性項相当の状態量が複合された状態量であ り, 軌道計画時の運動学制約との併用が複雑となる。一方で, 静 力学を考慮した射影・低次元化モデルとしては, 重心実行可能 領域への射影 [18] [19] などが行われており，これは重心位置が 直接含まれる領域を表すため, 運動学制約との併用が容易であ
る。これらを踏まえ，バランス制約の考慮・射影手法の観点での 本提案手法の特徵は以下である.（a）動力学を考慮する重心実 行可能領域が静力学と同様に得られることを示し, 静力学・動 力学双方を考慮可能な重心実行可能領域計算法を示す。これに より動力学を考慮しながらも, 軌道計画時の運動学制約と併用 が容易な重心位置の領域を求めることができる（b) 射影計算 としては, Multi-parametric Programming [20], Double Description Method [21], 直接的に射影を行う方法 [16] [18] [19] などが挙げられるが，本稿では線形計画法を用いた繰り返し近 似計算 [16] を拡張して用いる.

2.3.2 多様な制約を考慮する粗密段階計算による軌道計画

ヒューマノイドロボットの従来研究に扔いて, 多様な制約を 考慮した軌道計画法が提案されてきている，粗密段階計算を行 う例として，キーポーズ計算として静力学を考慮し，準静的に 補間を行うことで軌道を得る方法 [2] [22]～[25]，干渉回避を伴 い動的な補間を行う方法 [26]〜 [28], 効率的な動的補間法 [29] な どが提案されている。これらを踏まえ，軌道計画の観点での本 提案手法の特徴は以下である。（a）遊脚期・支持脚期のキーフ レームを考慮し，動的な軌道計画を可能とする。（b）重心実行 可能領域の幾何的な特徽を利用し，重心実行可能領域に重心が 含まれ，かつ領域境界から極力余裕のあるロバストなキーポー ズ解を得る。(c) バランス制約・運動学制約の両者を考慮可能 なキーポーズ計算・補間方法を提供する.

\section{3. バランス制約の重心実行可能領域への射影計算法}

本章では動力学的バランス制約が静力学的バランス制約同様 に重心実行可能領域に射影可能であることを示し，近似的な射 影計算方法を利用し静力学・動力学双方の重心実行可能領域を 得る方法を提案する。 バランス制約を重心実行可能領域に射影 することで以下の利点が見込まれる。（a）バランス制約は接触 レンチを含み変数が高次元となるが，重心の領域へと射影する ことで低次元化が可能となる．（b）低次元化により二次元ない し三次元空間が得られるため, バランス制約の可視化・解析など へ応用できる.（c）射影領域の幾何的特徵を軌道計画法で利用 できる，(a)，（b）の本章の次節以降で，(c) は次章で述べる.

\section{1 バランス制約の局所座標系表記}

本節では，静力学・動力学を考慮した射影を行うため，局所座 標系を利用したバランス制約の定式化を行う．大局的な挙動に 着目し，ロボットの運動方程式のうち重心に関係する六次元並 進回転成分のみ用いる，絶対座標系での総慣性力・原点まわり の総慣性モーメントの力学平衡式および接触制約は以下になる.

$$
\boldsymbol{G w}=\left[\begin{array}{c}
M\left(\ddot{\boldsymbol{p}}_{G}-\boldsymbol{g}\right) \\
\dot{\boldsymbol{L}}_{G}-\left(M\left(\ddot{\boldsymbol{p}}_{G}-\boldsymbol{g}\right) \times \boldsymbol{p}_{G}\right)
\end{array}\right]
$$

$\boldsymbol{w} \in R^{6 N_{L}}$ は接触レンチベクトルであり, $N_{L}$ は接触点数であ る. $M$ は総質量, $\boldsymbol{p}_{G}=\left[\begin{array}{ll}x_{G} & y_{G} z_{G}\end{array}\right]^{T}$ はロボット全体の重心位 置である. $g$ を重力加速度として $\boldsymbol{g}=\left[\begin{array}{lll}0 & 0 & -\end{array}\right]^{T}$ であり, $\boldsymbol{L}_{G}$ は角運動量である。 $\boldsymbol{C}$ は線形化した摩擦すい制約, $\boldsymbol{w}$ の上下 限制約，圧力中心制約などを含む接触制約である， $\boldsymbol{b}$ は制約境 
界ベクトルである. $\boldsymbol{G}, \boldsymbol{C}, \boldsymbol{b}$ の定義は付録 A に述べる.

次に，ある時刻の総加速度 $\ddot{\boldsymbol{p}}_{G}-\boldsymbol{g}$ に着目し，その時刻の式 （1）の性質を明らかにするため，局所座標系を便宜的に導入す る. 局所座標系は, 原点位置が絶対座標系原点位置と一致し, Z 軸が総加速度 $\ddot{\boldsymbol{p}}_{G}-\boldsymbol{g}$ の方向を向き, 姿勢を表す回転行列 $\boldsymbol{R}_{G}$ が次を満たすとする。

$$
\boldsymbol{R}_{G}(-\overline{\boldsymbol{g}})=\ddot{\boldsymbol{p}}_{G}-\boldsymbol{g}
$$

ここで $\overline{\boldsymbol{g}}=\left[\begin{array}{lll}0 & 0 & -\bar{g}\end{array}\right]^{T}, \bar{g}=\left|\ddot{\boldsymbol{p}}_{G}-\boldsymbol{g}\right|$ である.ここでは $\ddot{\boldsymbol{p}}_{G}-\boldsymbol{g} \neq \mathbf{0}$ とし, $\ddot{\boldsymbol{p}}_{G}-\boldsymbol{g}=\mathbf{0}$ の場合の扱いは次節で述べる. また局所座標系は静止座標系とする。 そのためある時刻では式 （2）の関係を持つが，ロボットあるいは重心と連動する動座標 系でないため, 以降の局所座標系への変換ではコリオリカ・遠 心力は生じない，式（1）の等式を局所座標系で置き換え次を 得る.

$$
\overline{\boldsymbol{G}} \boldsymbol{w}=\left[\begin{array}{c}
-M \overline{\boldsymbol{g}} \\
\dot{\overline{\boldsymbol{L}}}_{G}+M \overline{\boldsymbol{g}} \times \overline{\boldsymbol{p}}_{G}
\end{array}\right]
$$

ここで

$$
\overline{\boldsymbol{G}}=\left[\begin{array}{cc}
\boldsymbol{R}_{G}^{T} & \mathbf{0} \\
\mathbf{0} & \boldsymbol{R}_{G}^{T}
\end{array}\right] \boldsymbol{G}, \quad \overline{\boldsymbol{p}}_{G}=\boldsymbol{R}_{G}^{T} \boldsymbol{p}_{G}, \quad \dot{\overline{\boldsymbol{L}}}_{G}=\boldsymbol{R}_{G}^{T} \dot{\boldsymbol{L}}_{G}
$$

とし, $\overline{\boldsymbol{p}}_{G}=\left[\begin{array}{lll}\bar{x}_{G} & \bar{y}_{G} & \bar{z}_{G}\end{array}\right]^{T}, \overline{\boldsymbol{L}}_{G}=\left[\begin{array}{lll}\bar{L}_{G x} & \bar{L}_{G y} & \bar{L}_{G z}\end{array}\right]^{T}$ とする. 式（3）は $\bar{z}_{G}$ を含まないため, 式 (3) の等式条件は二つの等 式に分解できる，以上より式（3）は次となる.

$$
\begin{gathered}
{\left[\begin{array}{c}
\bar{x}_{G} \\
\bar{y}_{G}
\end{array}\right]=\left[\begin{array}{l}
\overline{\boldsymbol{d}}_{x}^{T} \\
\overline{\boldsymbol{d}}_{y}^{T}
\end{array}\right] \boldsymbol{w}+\left[\begin{array}{l}
\bar{l}_{x} \\
\bar{l}_{y}
\end{array}\right]} \\
\overline{\boldsymbol{G}}_{n} \boldsymbol{w}=\overline{\boldsymbol{w}}_{n} \\
\boldsymbol{C \boldsymbol { w }} \geq \boldsymbol{b}
\end{gathered}
$$

ここで

$$
\begin{gathered}
{\left[\begin{array}{c}
\overline{\boldsymbol{d}}_{x}^{T} \\
\overline{\boldsymbol{d}}_{y}^{T}
\end{array}\right]=\left[\begin{array}{cccc}
\mathbf{0}_{3}^{T} & 0 & -\frac{1}{M \bar{g}} & 0 \\
\mathbf{0}_{3}^{T} & \frac{1}{M \bar{g}} & 0 & 0
\end{array}\right] \overline{\boldsymbol{G}}} \\
\overline{\boldsymbol{G}}_{n}=\left[\begin{array}{cccc}
\boldsymbol{E}_{3} & 0 & 0 & 0 \\
\mathbf{0}_{3}^{T} & 0 & 0 & 1
\end{array}\right] \overline{\boldsymbol{G}} \\
\bar{l}_{x}=\frac{\dot{\bar{L}}_{G y}}{M \bar{g}}, \quad \bar{l}_{y}=-\frac{\dot{\bar{L}}_{G x}}{M \bar{g}}, \quad \overline{\boldsymbol{w}}_{n}=\left[\begin{array}{llll}
0 & 0 & M \bar{g} & \dot{\bar{L}}_{G z}
\end{array}\right]^{T}
\end{gathered}
$$

であり, $\boldsymbol{E}_{3}$ は $3 \times 3$ 次元単位行列, $\mathbf{0}_{3}$ はゼロベクトルとする.

\section{2 重心実行可能領域への射影}

次に静力学・動力学的に制約を満たす重心実行可能領域の導 出を行う． $\ddot{\boldsymbol{p}}_{G}$ と $\dot{\boldsymbol{L}}_{G}$ を既知とみなし，式（5）㧍よび式 (6) による $\boldsymbol{w}$ の集合は凸多面体となる. 式（4）による重心位置 $\left[\bar{x}_{G} \bar{y}_{G}\right]^{T}$ への射影はアフィン変換であり, 凸多面体のアフィン 変換の像も凸多面体であるため ${ }^{\dagger}$, 重心実行可能領域も凸多面 体となる， $\bar{z}_{G}$ はこれらの式に含まれないので, 重心実行可能領

\footnotetext{
†凸多面体の線形変換は凸多面体である $[30]$ のと同様に，凸多面体のア フィン変換が凸多面体であることを示せる.
}

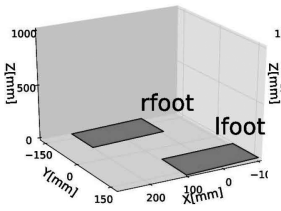

(a) Sole Polygons

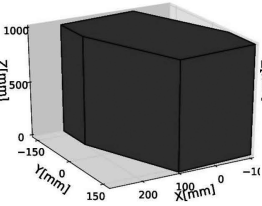

(b) SCFR

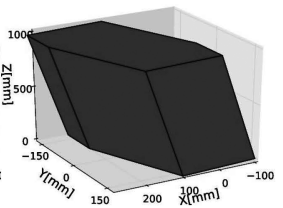

(c) DCFR
Fig. 4 CFR examples in biped standing. For (c), $\ddot{\boldsymbol{p}}_{G}$ is $\left[\begin{array}{lll}1 & 0 & 0\end{array}\right]^{T}$ $\left[\mathrm{m} / \mathrm{s}^{2}\right]$ and $\dot{\boldsymbol{L}}_{G}=\mathbf{0}$. CFRs where $\bar{z}_{G}$ are within [0 1000] $[\mathrm{mm}]$ are displayed. DCFR is a tilted prism. rfoot is a right foot and lfoot is a left foot

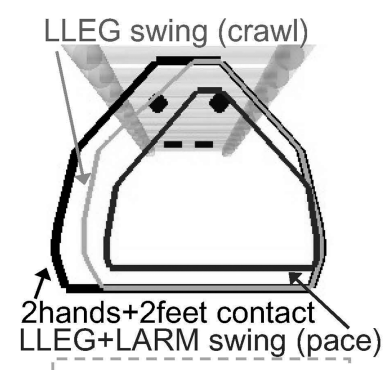

(a) Vertical climbing

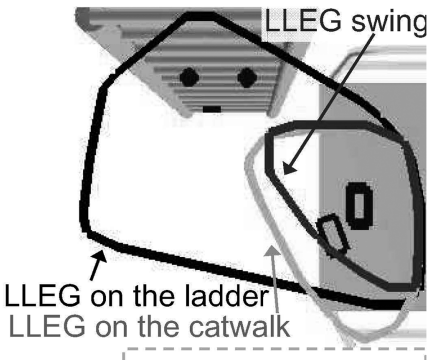

(b) Ladder transition
Fig. 5 SCFR examples for hands-feet contacts (top views) Hands and feet positions (black points and rectangles) and SCFRs in different hands-feet contact. LARM and LLEG are a left arm and a left leg, respectively

域は $\left[\bar{x}_{G} \bar{y}_{G}\right]^{T}$ の領域を表す二次元凸多面体となる。もしくは， 局所座標系の Z 軸方向に無限に伸び先述の二次元凸多面体を断 面とする三次元凸多角柱としても良い。跳躍のように過大な加 速度を生じ $\ddot{\boldsymbol{p}}_{G}-\boldsymbol{g}=\mathbf{0}$ となる場合， $\boldsymbol{p}_{G}$ は式（1）に含まれ ず重心実行可能領域は $R^{3}$ となる. 本稿では $\ddot{\boldsymbol{p}}_{G}=\dot{\boldsymbol{L}}_{G}=\mathbf{0}$ の 場合の領域を静的重心実行可能領域（Static CFR, SCFR）と よぶ. SCFR の場合, $\boldsymbol{g}$ と $\overline{\boldsymbol{g}}$ は常に一致し, 局所座標系計算を 省くことができる，なお，水平な床面上にロボットが接地して いる場合は，床面高さでの SCFR の多角形と支持多角形は等価 である. 既知の $\ddot{\boldsymbol{p}}_{G}$ と $\dot{\boldsymbol{L}}_{G}$ から計算される領域を動的重心実行 可能領域（Dynamic CFR, DCFR）とよぶ. 式 (4)〜 (6) に より求まる二次元の重心実行可能領域は必ずしも有界でないが, $\ddot{\boldsymbol{p}}_{G}-\boldsymbol{g} \neq \mathbf{0}$ 㧍よび付録 B のように接触レンチの上下限を考慮 することにより，以降では有界として考える。

Fig. 4 にロボットの 2 足が同一水平面上に接地している例を 示す. Fig. 4 (a) が左右足平, Fig. 4 (b) が SCFR, Fig. 4 (c) が $\ddot{\boldsymbol{p}}_{G}=\left[\begin{array}{lll}1 & 0 & 0\end{array}\right]^{T}\left[\mathrm{~m} / \mathrm{s}^{2}\right], \dot{\boldsymbol{L}}_{\boldsymbol{G}}=\mathbf{0}_{3}$ としたDCFR である. SCFR は足裏支持多角形を鉛直方向に伸ばした角柱となり，DCFR は 傾斜した角柱となっているのが分かる．また，この際の傾斜方 向は，倒立振子が上記加速度で運動する場合に動的平衡を保て る傾斜方向と一致する。次に，Fig. 5 に (a) 垂直はしご昇降時, (b) はしごへの乗り移り動作時の SCFR を示す. 複雑な手先足 先接触，クロール・ペースといった歩容の違いがあっても同様 に重心の領域を得られることが分かる.

\section{3 バランス制約の繰り返し計算による射影法}

次に射影領域の計算法を導入する，前節により局所座標系を 導入することで SCFR，DCFR 双方が同一の式で表現される ことが示された．本稿での射影アルゴリズム概要を Fig. 6 に示 


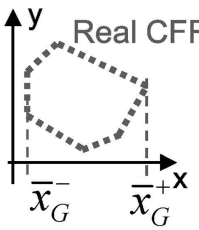

Step1

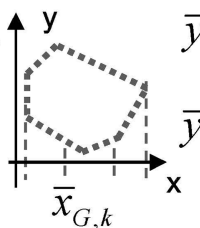

Step2

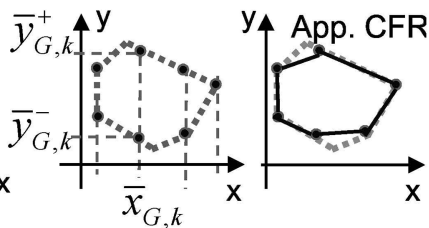

Step3

Step4

Fig. 6 Concept of projection of balance constraints

す.アルゴリズムは文献 [16] を拡張し, 線形計画法を用い低次 元空間から高次元空間まで段階的に計算する. 次のような $\bar{x}_{G}$ と $\bar{y}_{G}$ の最大最小を求める線形計画法を考える.

$$
\begin{gathered}
\min _{\boldsymbol{w}} \bar{x}_{G}^{-}=\overline{\boldsymbol{d}}_{x}^{T} \boldsymbol{w}+\bar{l}_{x} \\
\text { s.t. } \overline{\boldsymbol{G}}_{n} \boldsymbol{w}=\overline{\boldsymbol{w}}_{n}, \quad \boldsymbol{C} \boldsymbol{w} \geq \boldsymbol{b} \\
\max _{\boldsymbol{w}} \bar{x}_{G}^{+}=\overline{\boldsymbol{d}}_{x}^{T} \boldsymbol{w}+\bar{l}_{x} \\
\text { s.t. } \overline{\boldsymbol{G}}_{n} \boldsymbol{w}=\overline{\boldsymbol{w}}_{n}, \quad \boldsymbol{C} \boldsymbol{w} \geq \boldsymbol{b}
\end{gathered}
$$

$$
\begin{array}{cl}
\min _{\boldsymbol{w}} & \bar{y}_{G, k}^{-}=\overline{\boldsymbol{d}}_{y}^{T} \boldsymbol{w}+\bar{l}_{y} \\
\text { s.t. } \overline{\boldsymbol{G}}_{n} \boldsymbol{w}=\overline{\boldsymbol{w}}_{n}, & \boldsymbol{C} \boldsymbol{w} \geq \boldsymbol{b}, \quad \bar{x}_{G, k}=\overline{\boldsymbol{d}}_{x}^{T} \boldsymbol{w}+\bar{l}_{x} \\
\max _{\boldsymbol{w}} & \bar{y}_{G, k}^{+}=\overline{\boldsymbol{d}}_{y}^{T} \boldsymbol{w}+\bar{l}_{y} \\
\text { s.t. } \overline{\boldsymbol{G}}_{n} \boldsymbol{w}=\overline{\boldsymbol{w}}_{n}, & \boldsymbol{C} \boldsymbol{w} \geq \boldsymbol{b}, \quad \bar{x}_{G, k}=\overline{\boldsymbol{d}}_{x}^{T} \boldsymbol{w}+\bar{l}_{x}
\end{array}
$$

アルゴリズムの計算手順は以下となる

Step1 式 $(7 \mathrm{a})$ より $\bar{x}_{G}$ の最小值 $\bar{x}_{G}^{-}$を, 式 $(7 \mathrm{~b})$ より最大值 $\bar{x}_{G}^{+}$を求める.

Step2 $\left[\bar{x}_{G}^{-}, \bar{x}_{G}^{+}\right]$から $K_{p}$ 個の点をサンプルする。例えば, $\bar{x}_{G, 0}=\bar{x}_{G}^{-}, \bar{x}_{G, K_{p}-1}=\bar{x}_{G x}^{+}$として, $\left[\bar{x}_{G, 0}, \ldots\right.$, $\left.\bar{x}_{G, k}, \ldots, \bar{x}_{G, K_{p}-1}\right]$ のようにサンプルを行う.

Step3 各 $\bar{x}_{G, k}$ の值を式 (8a) の等式条件に追加し, $\bar{y}_{G, k}$ の最 小值 $\bar{y}_{G, k}^{-}$を求める。同様に, 式 $(8 \mathrm{~b})$ により $\bar{y}_{G, k}$ の 最大值 $\bar{y}_{G, k}^{+}$を求める.

Step4 全 $\left[\bar{x}_{G, k} \bar{y}_{G, k}^{-}\right]^{T},\left[\bar{x}_{G, k} \bar{y}_{G, k}^{+}\right]^{T}$ の点列の凸包を求め, こ れを近似した重心実行可能領域とする.

これにより, span 形式（V 表現, 内部表現ともよばれる）の射 影を得る. Step4の点列は真の CFR の辺上に存在するため, 得 られる近似 CFR は真の CFR に内包され, 元々のバランス制約 を侵害しない. Step3では, 先に最小值をすべて求め次に最大 值を求めており，各 $\bar{x}_{G, k}$ で最小最大を交互に求める方法より も多くの場合で効率的となる。これは前者の場合, 式 (8a) と 式 $(8 \mathrm{~b})$ の評価関数の変化する回数を減らし, 一つ前の線形計 画法の結果を再利用し計算効率を高めることができるためであ る.なお，このアルゴリズムは CWSへの射影といった多次元 射影に適用できる，つまり， $k$ 次元の凸多面体から Step2 でサ ンプル点を選び，それぞれのサンプル点に対し第 $k+1$ 成分の 最大最小を求め, $k+1$ 次元の凸多面体を求めることができる.

なお，式（2）の性質を持つ $\boldsymbol{R}_{G}$ の $\mathrm{X}, \mathrm{Y}$ 軸方向は一意に決 定されない。しかし次章以降の軌道計画など多くの場合で, 絶 対座標系である式（1）功局所座標系である式（3）へ変換し CFR を求め, その後絶対座標系などに変換し直して CFR を

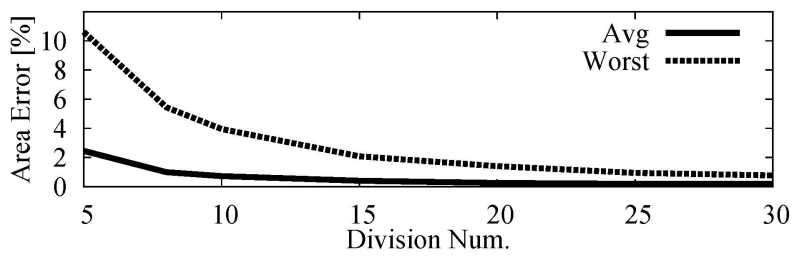

Fig. 7 Division num. $\left(K_{p}\right)$ - SCFR approximation error. Tested biped and quad walking, and ladder tasks (Sec. 6)

利用しており，局所座標系の $\mathrm{X} ， \mathrm{Y}$ 軸の違いは相殺される。絶 対座標系での CFR を求める際， $\boldsymbol{R}_{G}$ の定義による差異が真の CFR の場合は相殺されるが，本節の繰り返し計算の $\mathrm{X} ， \mathrm{Y}$ 軸 の取り方により近似 CFR の場合は差異が出得る点に留意する。 また, DCFR が二次元凸多面体または三次元凸多角柱となる点 に留意し，局所座標系を介さず DCFR を求めることもできる.

\section{4 接触制約の表現法}

関連研究の多くで，接触部位の各点に作用する三次元接触力 により接触を表現する方法が採用されるが，本稿では接触を接 触部位単位の六次元接触レンチで表現する（付録 A). 六次元接 触レンチの表記のほうが不等式制約が複雑になる代わりに，変 数次元が削減できるほか，次のような利点がある．制約境界か ら遠いロバストな解を得るために，摩擦係数を小さく設定する 方法 [9] [19] は六次元接触レンチ, 三次元接触力の両表現で利用 可能である。一方六次元接触レンチの場合，不等式制約の行列 $\boldsymbol{C}$ に摩擦係数だけでなく圧力中心制約の接触面の辺長さも含ま れている，そのため，摩擦制約だけでなく圧力中心制約のマー ジンおよびロバストさを定量的に扱うことが容易である.

\section{5 重心実行可能領域射影計算の近似結果}

先述の射影アルゴリズムの精度を評価した.ここでは SCFR の射影を対象とし，真の SCFR は $x_{G}-y_{G}$ 平面を全探索的に サンプルし，式（3）の制約を受ける二次計画法を解いて得た. Fig. 7 に分割数 $K_{p}$ と面積の近似誤差との関係を示す. $K_{p}$ が多 いほど近似精度が高いが，例えば， $K_{p}=8$ ほどで平均 $1 \%$ ，最悪 值で $5 \%$ 程度の誤差となり，良い近似を得られることが分かる.

\section{4. 重心実行可能領域を利用するキーポーズ生成法}

キーポーズ生成は，関節角，腰位置姿勢，重心位置，CWS を 含むキーポーズを各キーフレームでの運動学制約とバランス制 約を満たすように求める問題と定式化できる．重心実行可能領 域への射影により，キーポーズ生成は関節角，腰位置姿勢，重 心位置を各キーフレームで運動学制約と重心制約を満たすよう に求める問題となる。本章では，運動学制約および重心制約を 満たすように逆運動学計算を解くキーポーズ生成法を提案する。

\section{1 キーポーズ生成法概要}

Fig. 8 にキーポーズ生成の概要を示す. 提案手法は, (a) SCFR と DCFR を使う方法，（b） SCFRのみを使う方法の 両者に適用でき，(b) はヒューマノイドロボットの軌道計画の 従来研究に見られる方法であるが，(a) は特に本稿の特徴とな る動的なキーポーズ生成を可能にする方法である。（a）の方法 の手順は以下である. (Step1）支持脚期・遊脚期の切り替わり のフレームでバランス制約を SCFR へ射影し，代表重心位置を 


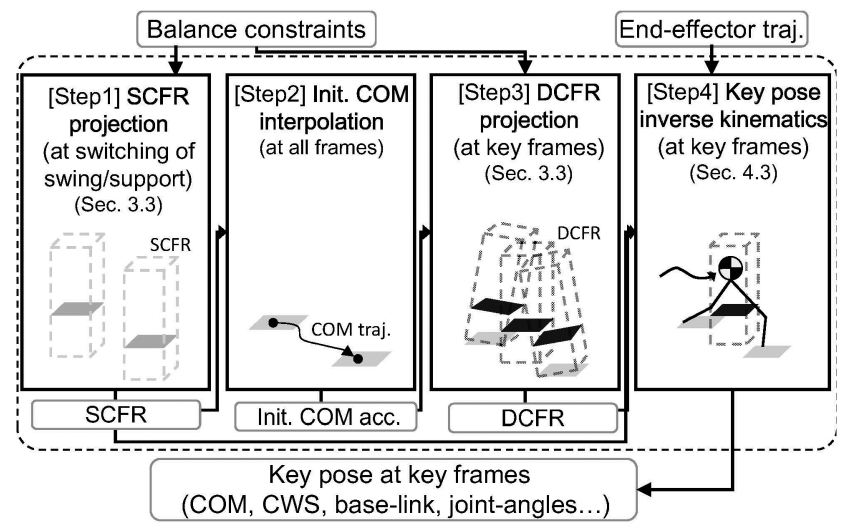

Fig. 8 Overview of key pose generation

計算する.（Step2）文献 [31]〜 [33] のような低次元化モデルを 利用し SCFR の代表重心位置を補間することで, 初期解として の重心・重心加速度 $\ddot{p}_{G}$ の軌道を得る. 角運動量軌道も同様に求 めても良く, $\dot{\boldsymbol{L}}_{G}=\mathbf{0}$ としても良い. (Step3) 得られた $\ddot{\boldsymbol{p}}_{G}$ と $\dot{\boldsymbol{L}}_{G}$ に基づき各キーフレームでの DCFR を計算する。（Step4） 各キーフレームでロボット重心が DCFR を満たすよう逆運動 学を解き，キーポーズ列を得る。初期重心軌道は最終的に得ら れる重心軌道と異なるため, 初期重心軌道から得られる DCFR は最終的な DCFR とは異なる。接触制約にハードマージンを 用いて DCFR の領域を減らすことで，これらの差異に対応す る.（b）の方法の手順の場合，（Step2）の初期重心軌道補間と （Step3）の DCFR 計算を省き，(Step4）で直接 SCFR をキー ポーズ計算に用いる.

\section{2 目標重心位置計算}

キーポーズ生成では，運動学制約および重心制約ともに制約 を満たすことが必要であり, 制約境界から極力遠いロバストな 解を得ることが望ましい. 重心制約に関しては, ロボット重心 が実行可能領域に含まれる必要があり，また領域境界から極力 余裕のある位置に重心が存在することが望ましい，本稿では簡 易にこれを実現すべく, 領域の凸多角形の幾何的な重心点の位 置を逆運動学の目標重心位置とする. 前節のとおり接触レンチ を有界にしているため重心実行可能領域も有界であり, 目標重 心位置が定義できる。逆運動学ではロボットの現在重心位置が 目標重心位置に漸近するようフィードバックすることで, 領域 への内包と領域境界から遠ざかることの 2 点が実現できる. な 扮局所座標系の重心 $\mathrm{Z}$ 成分 $\bar{z}_{G}$ は上記の方法では決定できない ため, 目標重心 Z 成分はユーザが定義可能なパラメタとする.

\section{3 キーポーズ計算のための逆運動学}

目標重心位置に漸近し運動学的に実行可能なキーポーズを, 全身関節を利用する逐次二次計画法による逆運動学で計算する。

$$
\begin{gathered}
\min _{\boldsymbol{\Delta} \boldsymbol{q}, \boldsymbol{e}}|\boldsymbol{\Delta} \boldsymbol{q}|_{\boldsymbol{W}_{a}}^{2}+\sum_{k}\left|\boldsymbol{J}_{k} \boldsymbol{\Delta} \boldsymbol{q}-\boldsymbol{\Delta} \boldsymbol{x}_{k}\right|_{\boldsymbol{W}_{k}}^{2}-\boldsymbol{v}^{T} \boldsymbol{e} \\
\text { s.t. } \xi\left(\boldsymbol{q}^{+}-\boldsymbol{q}_{0}\right)-\boldsymbol{e} \geq \boldsymbol{\Delta} \boldsymbol{q} \geq \xi\left(\boldsymbol{q}^{-}-\boldsymbol{q}_{0}\right)+\boldsymbol{e} \\
\boldsymbol{J}_{c o l} \boldsymbol{\Delta} \boldsymbol{q} \geq \boldsymbol{\Delta} \boldsymbol{x}_{c o l}, \quad \boldsymbol{e} \geq \mathbf{0}
\end{gathered}
$$

各キーフレームで, 式 $(9)$ を繰り返し計算する， $N_{d o f}$ を関節 自由度とし， $\boldsymbol{\Delta} \boldsymbol{q} \in R^{6+N_{\text {dof }}}$ をコンフィギュレーション（腰の 運動㧍よび関節角度を含む) の差分とする． $\boldsymbol{q}_{0}$ はコンフィギュ
レーション初期值である． $\boldsymbol{J}_{k}$ は作業空間とコンフィギュレー ション空間を対応付ける行列である. $\Delta \boldsymbol{x}_{k}$ は作業空間の差分で あり，目標エンドエフェクタ位置姿勢，目標腰位置姿勢，目標関 節角，掠よび目標重心位置より計算する，W $\boldsymbol{W}$ を正定值重み行列 として, $|\boldsymbol{x}|_{\boldsymbol{W}}^{2}$ を $\boldsymbol{x}^{T} \boldsymbol{W} \boldsymbol{x}$ とする. 重心, 腰位置姿勢, 関節角 に関してはエンドエフェクタよりも小さい重みを設定すること で，エンドエフェクタ制約を優先的に守るよう設定する．特に 重心は目標重心位置に厳密に一致している必要がなく, CFRに 含まれて入れば良いためである. $\boldsymbol{q}^{+/-}$は関節可動域上下限であ る. $\xi$ は定数係数であり, $\boldsymbol{J}_{c o l}$ 抢よび $\boldsymbol{\Delta}_{\boldsymbol{x}_{c o l}}$ は干渉回避のため の不等式制約である [34]. マージンベクトル $\boldsymbol{e}$ は関節可動域限 界からの極力余裕のある解を得るソフトマージンとして導入し ており，vは非負の重みベクトルである。 ハードマージンとし て, 関節可動域の上下限をキーポーズ生成段階で減じる. 上式 には各キーフレーム間の速度制約を考慮することも可能である.

各キーフレームでの逆運動学の終了条件としては, エンドエ フェクタの目標への収束と，ロボット重心が CFR へ含まれる かどうかを判定する。バランス制約を式（1）により直接判定す る方法と比較し, CFR の判定は二次元凸多角形への重心の内包 を判定するだけでよく，高速に計算できる.

\section{5. 全身軌道生成法}

キーポーズ列は粗なキーフレームでの運動情報であるため, 補 間・最適化を行うことで密な軌道を計算する，将来に渡る運動目 標を満たすように全身軌道を計算することが有効であり，(a) 予 測区間を 1 フレームとする方法（本稿で瞬時計算とよぶ），(b) 1フレームより大きい定数とする方法などが考えられる。また 考える状態量としても，(A）重心などの低次元化モデルを利用 する方法，（B）全身の関節角・トルクを利用する方法などが考 えられる、本稿では，キーポーズ列から直接全身軌道を求める （すなわち B かつ b) のでなく, 従来研究と同様に重心など代 表的な状態量の補間を行い $(\mathrm{A}$ かつ $\mathrm{b})$, 最後に各時刻で瞬時最 適化計算（B かつ a) を行うことで最終的な軌道を求める.

\section{1 キーポーズ補間}

キーポーズから得られるキーフレームでの重心位置, 腰姿 勢，関節角などを動力学を考慮し補間する．特に重心の補間に は，近年ヒューマノイドロボット分野で用いられている（例え ば文献 [35] [36])，モデル予測制御（Model Predictive Control, $\mathrm{MPC}$ )を用いる。ここでは運動量・角運動量などを状態量に持 ち, 線形状態方程式を利用し一定の予測区間で接触制約を考慮 可能とする補間を行う。

\subsubsection{MPC を用いた重心列補間}

キーポーズ重心列の補間のため, 離散化した線形時不変状態 方程式を用いて鉛直重心軌道を求め, 次に線形時変状態方程式 を用いて水平重心軌道を求める. MPC による補間自体は重心に 関連する低次元化モデルを用い，バランス制約（C4）のみを考 慮するものであるが，本稿では MPC の重心軌道参照值をキー ポーズ列に基づき与えることで，運動学制約（C1〜3）も近似 的に考慮する点が特徵である.

5.1.2 MPC の解法

考慮する状態方程式は次の形式とする 


$$
\begin{gathered}
\boldsymbol{x}_{k+1}=\boldsymbol{A}_{k} \boldsymbol{x}_{k}+\boldsymbol{B}_{k} \boldsymbol{u}_{k} \\
\boldsymbol{y}_{k}=\boldsymbol{C}_{k} \boldsymbol{x}_{k}+\boldsymbol{D}_{k} \boldsymbol{u}_{k}
\end{gathered}
$$

各時刻で等式・不等式制約が課されるものとする.

$$
\boldsymbol{E}_{k} \boldsymbol{u}_{k} \geq \boldsymbol{f}_{k}, \quad \boldsymbol{G}_{k} \boldsymbol{u}_{k}=\boldsymbol{h}_{k}
$$

式（10）抢よび式（11）を $\boldsymbol{x}_{0}$ と $\boldsymbol{U}$ に関してまとめ次を得る.

$$
\begin{aligned}
& \boldsymbol{X}=\boldsymbol{A} \boldsymbol{x}_{0}+\boldsymbol{B U} \\
& \boldsymbol{Y}=\boldsymbol{C} \boldsymbol{x}_{0}+\boldsymbol{D} \boldsymbol{U}
\end{aligned}
$$

ここで, $\boldsymbol{X}=\left[\boldsymbol{x}_{1}^{T} \ldots \boldsymbol{x}_{N}^{T}\right]^{T}, \boldsymbol{U}=\left[\boldsymbol{u}_{0}^{T} \ldots \boldsymbol{u}_{N-1}^{T}\right]^{T}, \quad \boldsymbol{Y}=$ $\left[\boldsymbol{y}_{0}^{T} \ldots \boldsymbol{y}_{N-1}^{T}\right]^{T}$ とする. 以上を用いて, MPC を次の二次計画 法として定式化する。

$$
\begin{gathered}
\min _{\boldsymbol{U}}\left|\boldsymbol{X}-\boldsymbol{X}^{r e f}\right|_{\boldsymbol{W}_{1}}^{2}+|\boldsymbol{U}|_{\boldsymbol{W}_{2}}^{2}+\left|\boldsymbol{Y}-\boldsymbol{Y}^{\text {ref }}\right|_{\boldsymbol{W}_{3}}^{2} \\
\text { s.t } \quad \boldsymbol{E} \boldsymbol{U} \geq \boldsymbol{F}, \quad \boldsymbol{G} \boldsymbol{U}=\boldsymbol{H}
\end{gathered}
$$

式（15）を解くことで，キーポーズ重心列から得られる状態量 参照值 $\boldsymbol{X}^{r e f}$ とキーポーズ CWS 列から得られる出力参照值 $\boldsymbol{Y}^{r e f}$ からの誤差を最小化するような, 入力列 $\boldsymbol{U}$ と状態列 $\boldsymbol{X}$ を 得る. 式 (15) の等式·不等式制約は式（12）の全時刻分を連結 する. 最終的に状態列 $\boldsymbol{X}$ から鉛直・水平重心軌道などを得る.

5.1 .3 鉛直運動のための線形時不変システム

重心の鉛直運動のみを抽出し, 線形時不変システムを得る. $\boldsymbol{x}_{k}=\left[\begin{array}{lll}M z_{G} & M \dot{z}_{G}\end{array}\right]_{k}^{T}$ とする. 総慣性力 $\boldsymbol{u}_{k}=\left[F_{G z k}-M g\right]$ を 入力とする。等式条件, 式（11）の出力方程式, 式 (15) の $\boldsymbol{Y}$ は鉛直運動の定式化では利用しない. 接触制約を $F_{G z k}-M g$ に 射影する場合に, 上下限は重心実行可能領域と同様に線形計画 法で求まるので, 式 (15) は入力上下限制約のある一次元の二次 計画法となる. $T$ を時間刻みとし, 倸数行列は次のようになる.

$$
\boldsymbol{A}_{k}=\left[\begin{array}{ll}
1 & T \\
0 & 1
\end{array}\right], \boldsymbol{B}_{k}=\left[\begin{array}{c}
\frac{T^{2}}{2} \\
T
\end{array}\right]
$$

\subsection{4 水平運動のための線形時変システム}

重心の鉛直運動が求まれば, 重心の水平運動は線形時変システ

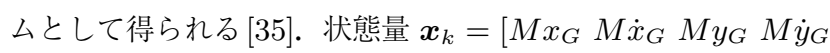
$\left.L_{G x} L_{G y}\right]_{k}^{T}$ は運動量・角運動量に関する項が含まれる. 出力 $\boldsymbol{y}_{k}=\left[\begin{array}{ll}N_{x} & N_{y}\end{array}\right]_{k}^{T}$ は原点まわりの総慣性モーメントである.入 力 $\boldsymbol{u}_{k}=\boldsymbol{w}$ は接触レンチである. 係数行列は次のようになる.

$$
\begin{gathered}
\boldsymbol{A}_{k=}=\left[\begin{array}{cccccc}
1 & T & 0 & 0 & 0 & 0 \\
0 & 1 & 0 & 0 & 0 & 0 \\
0 & 0 & 1 & T & 0 & 0 \\
0 & 0 & 0 & 1 & 0 & 0 \\
0 & 0 & -T F_{G z k} / M & 0 & 1 & 0 \\
T F_{G z k} / M & 0 & 0 & 0 & 0 & 1
\end{array}\right] \\
\boldsymbol{B}_{k}=\left[\begin{array}{cccccc}
\boldsymbol{B}_{0, k} & \ldots & \boldsymbol{B}_{N_{L}-1, k}
\end{array}\right] \\
\boldsymbol{B}_{i, k}=\left[\begin{array}{cccccc}
T^{2} / 2 & 0 & 0 & 0 & 0 & 0 \\
T & 0 & 0 & 0 & 0 & 0 \\
0 & 0 & T^{2} / 2 & 0 & 0 & 0 \\
0 & 0 & T & 0 & 0 & 0 \\
0 & -\beta_{i k} & T y_{i k} & T & 0 & 0 \\
\beta_{i k} & 0 & -T x_{i k} & 0 & T & 0
\end{array}\right]
\end{gathered}
$$

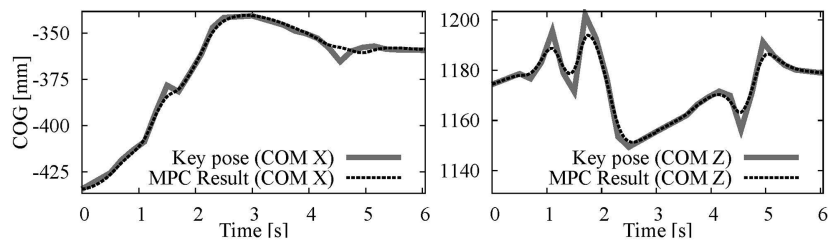

Fig. 9 COM interpolation by model predictive control

$$
\begin{gathered}
\boldsymbol{D}_{k}=\left[\begin{array}{ccc}
\boldsymbol{D}_{0, k} & \ldots & \boldsymbol{D}_{N-1, k}
\end{array}\right] \\
\boldsymbol{D}_{i, k}=\left[\begin{array}{cccccc}
0 & -z_{i k} & y_{i k} & 1 & 0 & 0 \\
z_{i k} & 0 & -x_{i k} & 0 & 1 & 0
\end{array}\right] \\
\boldsymbol{G}_{k} \boldsymbol{u}_{k}=\left[\boldsymbol{G}_{0, k} \ldots \boldsymbol{G}_{N_{L}-1, k}\right] \boldsymbol{u}_{k}=F_{G z k}, \quad \boldsymbol{G}_{i, k}=\boldsymbol{e}_{2,6}
\end{gathered}
$$

ここで, $\boldsymbol{p}_{i k}=\left[\begin{array}{lll}x_{i k} & y_{i k} & z_{i k}\end{array}\right]^{T}$ は第 $i$ 接触部位の位置であり $\beta_{i k}=-T\left(z_{i k}-z_{G k}\right)$ とする. 不等式条件は式 (1) と同様とす る. 等式条件は鉛直総慣性力 $F_{G z k}$ により設定する. $\boldsymbol{e}_{i, j} \in R^{j}$ は第 $i$ 成分が 1 の単位ベクトルである. $\boldsymbol{x}_{k}$ の参照值のうち $M x_{G}$ と $M y_{G}$ はキーポーズ重心列から設定し, 運動量参照值 は 0 とする. 角運動量参照值は文献 [32] に見られる多質点モデ ルやフライホイールモデルを用いてキーポーズ列から計算する か，もしくは 0 として設定する， $\boldsymbol{y}_{k}$ の参照值はキーフレーム での原点回りの CWS から求める.

\subsubsection{MPC による補間例}

Fig. 9 に補間例を示す．予測区間は 10 フレームとした，灰 色実線はキーポーズ重心列を線形補間したものである．Fig. 9 の黒色破線から, 滑らかでかつキーポーズ重心列に近い補間が 得られたことが分かる。また得られた軌道は制約を満たすだけ でなく，DCFRにより評価した重心領域境界までの最短距離が $128[\mathrm{~mm}]$ ほどであり，余裕のある補間ができていることが分 かる.

\section{2 瞬時全身逆運動学・接触力最適化計算}

前節までで得られたエンドエフェクタ・重心・腰姿勢軌道に 基づき関節角・トルク・接触レンチ軌道を生成する $[8]$. 具体的 には, 瞬時エンドエフェクタ・重心・腰姿勢を目標值として式 （9）に類似した逐次二次計画法により瞬時逆運動学計算を行う. さらに, 求まった運動が生じさせる総慣性力と等価な接触力最 適分配を，逆動力学および接触制約 $\mathrm{C} 4$, トルク制約 $\mathrm{C} 5$ を含め た次の二次計画法により求める.

$$
\begin{gathered}
\min _{\boldsymbol{w}} \quad|\boldsymbol{w}|_{\boldsymbol{W}_{w}}^{2}+\left|\overline{\boldsymbol{\tau}}-\boldsymbol{J}_{t}^{T} \boldsymbol{w}\right|_{\boldsymbol{W}_{t}}^{2} \\
\text { s.t. } \boldsymbol{G} \boldsymbol{w}=\overline{\boldsymbol{w}}, \quad \boldsymbol{C} \boldsymbol{w} \geq \boldsymbol{b}, \quad \boldsymbol{\tau}^{+} \geq \overline{\boldsymbol{\tau}}-\boldsymbol{J}_{t}^{T} \boldsymbol{w} \geq \boldsymbol{\tau}^{-}
\end{gathered}
$$

$J_{t}$ は接触レンチを関節トルクに変換する行列, $\tau^{+/-}$は関節卜 ルクの上下限である. $\overline{\boldsymbol{w}}$ は総慣性力・原点回りのモーメント, $\overline{\boldsymbol{\tau}}$ は関節トルクの慣性項であり, 両者は逆運動学で求まる運動か ら逆動力学で計算する．最終的に瞬時関節角，トルク，接触力 が求まり, 各時刻分統合して関節角軌道，トルク軌道，接触力 軌道を求める。提案手法では，キーポーズ生成・補間では関節 トルク以外の制約 $\mathrm{C} 1 \sim 4$ が考虑されるのに対し, 瞬時計算の工 程で関節トルクを含めた制約 $\mathrm{C} 1$ 〜 すべてが考慮される. 

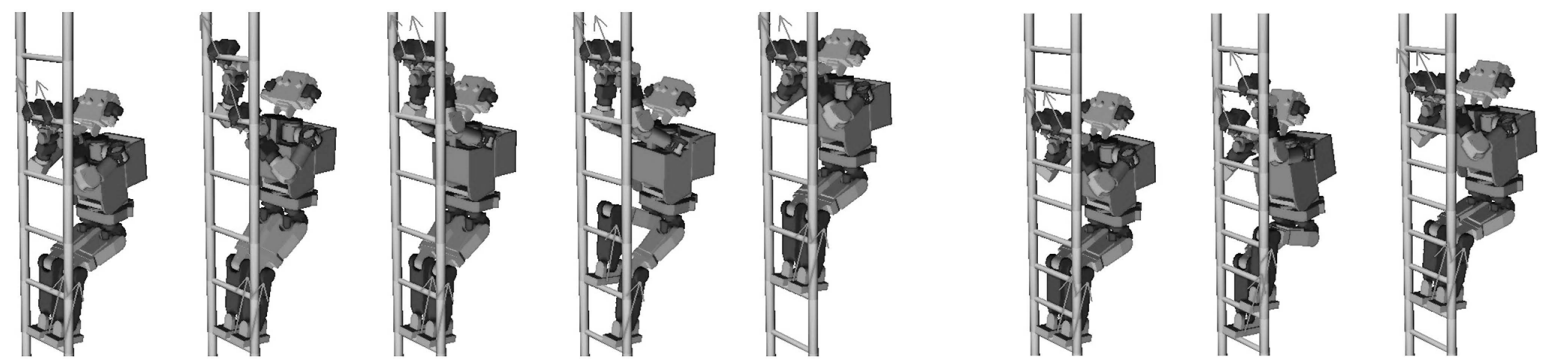

Fig. 10 Vertical ladder ascending with crawl (a)

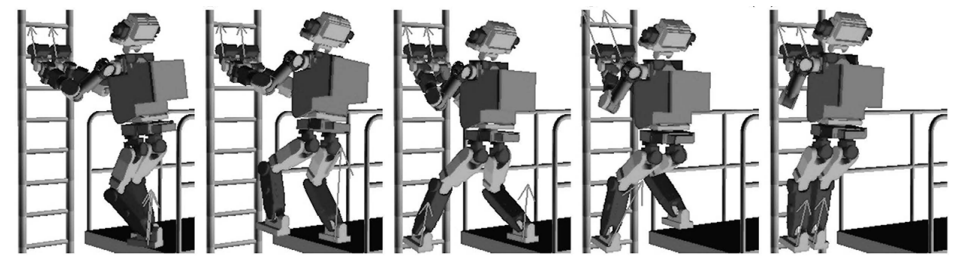

Fig. 11 Vertical ladder ascending with pace (b)

Fig. 12 Ladder-catwalk transition (c)

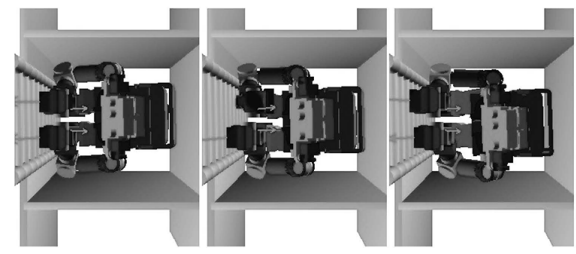

Fig. 13 Ladder ascending with obstacles (d) (top view)

\section{6. 多様な移動タスクでの軌道計画評価実験}

提案する軌道計画法を，はしご昇降・乗り移りを含む複数の 移動タスクに適用し, キーポーズ生成, 動力学的効果, 運動学 的効果, 実機適用の観点で評価を行った.

\section{1 実験条件・計算時間}

本評価実験では等身大ヒューマノイドロボット [8] の腕部寸 法等を変更しているロボットを用いた。ロボットは手先にはし ごの栈を把持するグリッパを有し, 手先足先に 6 軸力センサ, 胴体部に Inertial Measurement Unit（IMU）を搭載する。ロ ボットの身長は $1.675[\mathrm{~m}]$, 関節自由度数は 33 (腕部 $8 \times 2$, 脚 部 $6 \times 2$, 胴体部 2 , 頭部 1 , グリッパ $1 \times 2)$ である. 実機の 体重は $85[\mathrm{~kg}]$ であり実機運用時の軌道計画でもこの数值を利 用したが, 本稿の実機以外の軌道計画数值例では $80[\mathrm{~kg}]$ とし たものを揭載した.

軌道計画の所用時間の結果を以下に記す。軌道計画刻み $0.05[\mathrm{~s}]$ とした。一歩時間は $3[\mathrm{~s}]$ であり, 遊脚期 $2[\mathrm{~s}]$ で支持脚期 $1[\mathrm{~s}]$ とした。一歩分の軌道計画に要する平均時間は $4.4763[\mathrm{~s}]$ であ り，内訳はキーポーズ生成が $9.8 \%$ ，MPCによる補間が $77.9 \%$, 瞬時軌道計算が $12.4 \%$ あ゙った（Intel i7-4900MQ @ 2.80GHz で評価). 不等式拘束を考慮した MPC の補間計算に所用する時 間が多いが，例えば文献 [31] のように不等式拘束を省略するこ とにより, 計算時間の改善が期待できる. 提案手法の MPC の不 等式制約を省略した場合, 一歩分の軌道計画時間は $0.9976[\mathrm{~s}]$ 程 度であり，オンラインで軌道計画が可能であることが分かった。

\section{2 複数の移動タスクへの軌道計画の適用}

提案手法を次のような複数の移動タスク，(a) 栈高低差 350 [mm]の垂直はしごのクロール歩容による 3 段昇降（Fig. 10）, (b) 栈高低差 $225[\mathrm{~mm}]$ の垂直はしごのペース歩容による 3 段 昇降（Fig. 11)，(c) 栈・キャットウォーク間のクロール歩容に よる乗り移り（Fig. 12），(d) 障害物付き垂直はしごのクロー ル歩容による 1 段昇り (Fig. 13), (e) 2 足歩行，(f) 4 足歩行 へ適用した。提案手法により, 制約が厳しい条件下でも軌道計 画が可能であることを確認した，また，異なる環境，異なる歩

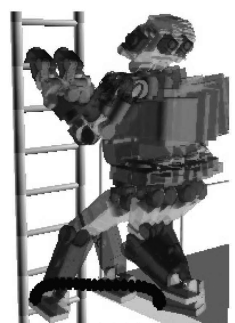

(a) LLEG swing

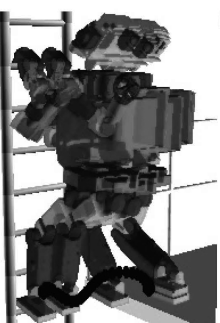

(b) RLEG swing

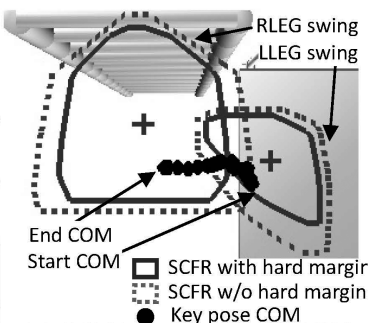

(c) SCFR and key pose COM
Fig. 14 Results of key pose generation. A key frame division is set to 12. In (a) and (b), we show key frames separated into three intervals for visualization. Black points in (a) and (b) show the original trajectories of end-effectors. In (c), the SCFRs with gray solid lines show the COP margin scaled by 0.45 and the friction coefficient margin scaled by 0.8 . The cross shapes within SCFRs are the centroids

容形態（クロール・ペース・ 2 足ないし 4 足歩行など）であっ ても，多様なバランス制約を重心実行可能領域計算により重心 制約として統一的に扱えるため, 提案手法により統一的に軌道 計画が可能であった.

\section{3 キーポーズ生成工程の評価}

提案手法に扔けるキーポーズ生成工程を評価した（本評価は Fig. 2 (b) の課題に対応する). Fig. 14 はキャットウォークから はしごへ左足，右足の順に遷移する様子である。ここでは結果の 説明を容易化すべく，SCFRのみを用いた例を示す．Fig. 14 (a) および (b) はキーポーズ生成結果である。得られたキーポーズ は, 運動学制約に応じて腰高さ・姿勢が変わっている. Fig. 15 にその一例を示す. Fig. 15 は左足の Y 位置（実線）と腰姿勢 の X 軸回り角度（破線）を示しており，第5〜第 10 フレーム 近辺ではしご乗り移りのために左足を出す際に腰姿勢が変化し ているのが分かる.Fig. 14 (c) の灰色破線揖よび灰色実線の多 角形はそれぞれ遊脚期中の SCFR である. 実線がハードマージ ンにより領域を減らしキーポーズ生成で利用される SCFR であ る。破線がハードマージンを考虑しない本来の SCFR であり, 比較のため表示した．黑点がキーフレーム重心列掞よびその始 


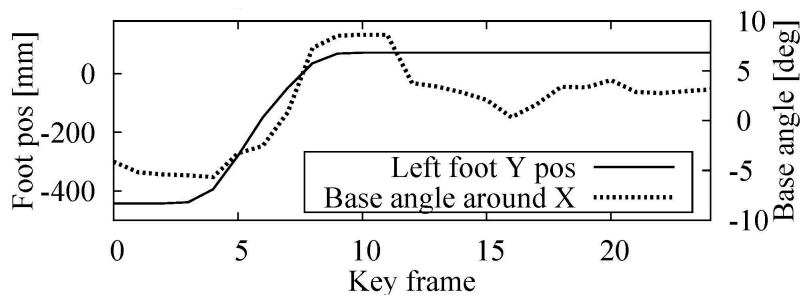

Fig. 15 Foot and base-link angle profiles while transition. Y axis is leftward and $\mathrm{X}$ axis is forward

点・終点である. 例えば左足遊脚期の際に, 直線的な補間など 単純な始点・終点の補間では遊脚期 SCFR を逸脱してしまいバ ランス維持できないことが分かる，遊脚期も考慮したキーポー ズ生成により，全キーフレーム重心列が実線の SCFR に含まれ ており，実行可能なキーポーズとなることが分かる．また，右 足遊脚期の重心列は SCFR の境界から遠ざかっており, ソフト マージンを大きくしていることが分かる. 以上より, 本提案手 法により支持脚期 - 遊脚期ともに, 実行可能でかつ極力制約境 界から遠ざかるキーポーズ生成が可能であることが示された。

\section{4 動力学的特性の評価}

提案手法における動力学的な特性を評価した. ここでは SCFR のみを利用する方法と, SCFR と DCFR 双方を利用する方法 とを比較した．どちらも MPCによる重心補間の段階では動的 な補間となって扔り, それ以前のキーポーズ生成段階で静力学を 考慮しているか動力学を考慮しているかの違いを比較する. 比 較を容易にするために一歩 $400[\mathrm{~mm}]$ の 2 足前進歩行例を挙げ, Fig. 16 に重心軌道㧍よびZMP 軌道を示す. DCFR を使うこ とでキーポーズ生成段階で動力学を考慮でき不要な加減速を抑 えられるため, DCFR を用いた方法の ZMP 変動（Fig. $16(\alpha)$ の黒色線）は SCFR のみを用いた方法（灰色線）よりも小さく なり，かつ足裏圧力中心制約（支持多角形）を侵害しない。ま た, キーポーズ生成段階では運動学制約に応じて重心高さが上 下し，脚伸びきりなどが回避される．SCFR を用いた方法では キーポーズ生成段階で重心位置が支持足裏上方に位置する必要 があるが，DCFRを用いた方法では加速度運動により重心位 置が支持足裹外に位置することもでき，足の伸びきりが生じに くい. 結果, DCFR を用いた重心高さ（Fig. 16 $(\beta)$ の破線）は SCFR のみを用いた重心高さ (実線) よりも重心の上下変動が 緩和される. 以上より, 本例では DCFR を使わなければ解を得 ることができず, DCFR を用いることで運動学的・動力学的に も不要な変動が抑制された．また， 2 足歩行における静歩行（準 静的歩行）と動歩行でも同様の違いが生じるため, 定性的には SCFR のみを使う方法を静歩行とした場合, DCFR も使う方法 は粗密段階計算に扮ける動歩行に相当するものと考元られる。

\section{5 運動学的特性の評価}

運動学的な特性を評価した（本評価はFig. 2 (a) の課題に対 応する)。ここでは, 支持脚期・遊脚期双方にキーフレームを設 定する方法 (Fig. 17 の “Swing Support”, 提案手法) と支持 脚期のみキーフレームを設定する方法 ("Support Only") を比

\footnotetext{
† "Joint ratio" は $r=\left|\left(2 q-\left(q^{+}+q^{-}\right)\right) /\left(q^{+}-q^{-}\right)\right| \in[0,1]$ により, "Velocity ratio"は $r=\left|\dot{q} / \dot{q}^{+}\right| \in[0,1]$ により, "Collision ratio" は $r=1 /($ distance +5.0$)$ により求めた.
}

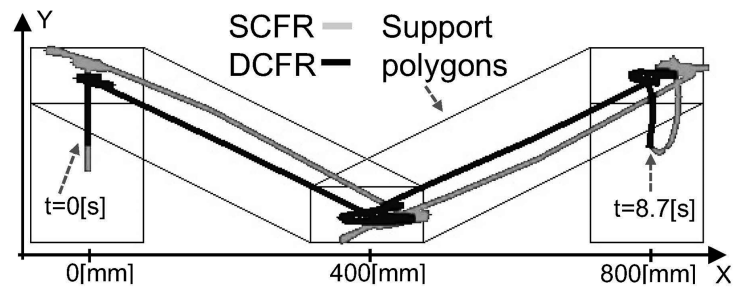

$(\alpha)$ ZMP trajectories in the horizontal plane (Top view)

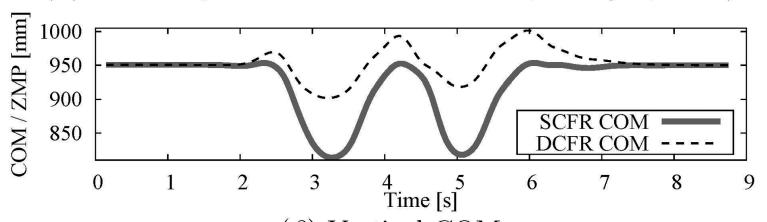

( $\beta$ ) Vertical COM

Fig. 16 Comparing SCFR and DCFR results (COM and ZMP)

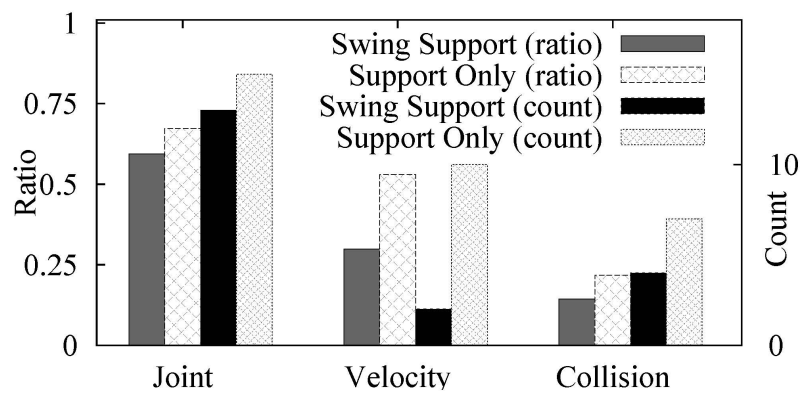

Fig. 17 Margins for joint angle, velocity, and collision. Solid histograms are the proposed method. They are smaller, e.g., better. "count"s are the number of joints over 0.7 Joint ratios and Velocity ratios, and that of collisions under $5.0[\mathrm{~mm}]$ distance

Table 1 Comparison of solvability of planner

\begin{tabular}{|c|c|c|c|c|c|c|c|}
\hline & $\begin{array}{l}\text { (a) } \\
\text { Ascend }\end{array}$ & $\begin{array}{l}\text { (a) } \\
\text { Desend }\end{array}$ & $\begin{array}{c}\text { (b) } \\
\text { Ascend }\end{array}$ & $\begin{array}{l}\text { (b) } \\
\text { Desend }\end{array}$ & $\begin{array}{c}(\mathrm{c}) \\
\text { To ladder }\end{array}$ & $\begin{array}{c}\text { (c) } \\
\text { From ladder }\end{array}$ & (d) \\
\hline SwingOnly & 0 & 0 & $x$ & $x$ & 0 & $x$ & 0 \\
\hline SwingSupport & O & O & O & O & O & O & O \\
\hline
\end{tabular}

較した. 第 6.2 節のはしごタスク (a)〜 (d) を対象として比較を 行い, Table 1 に各タスクでの軌道計画の可解性を示す，提案 方法 (“Swing Supprot”) では全ケースで軌道が得られたのに 対し, “Support Only”では瞬時計算で破綻が生じ解が得られ ないケースが存在した。この結果を運動学制約（関節可動域制 約，角速度制約，干渉回避制約）ごとにまとめたものを Fig. 17 に示す。ヒストグラム “ratio” は制約境界への近さを表す量で あり†, “count” は制約境界に近い制約数でありここれらははし ごタスク (a)〜 (d) それぞれの全時刻中の最悪值を求め, 最悪值 を全夕スク分平均して求めた. Fig. 17 より, “Swing Support" (提案手法) のほうが “Support Only”よりも制約から余裕の ある解が得られていた，具体的には，“Support Only” の場合， エンドエフェクタ軌道と重心軌道が適切な位置関係から乘離し た。これにより第 5 章の瞬時逆運動学計算の内部において, 無 理に重心追従を行うため過大な速度を生じ，またそのため可動 域上下限に近づきやすくリンク間距離も小さくなった。ささら 瞬時逆運動学計算内で重心・エフェク夕追従が十分でないか, 接 触レンチ最適化計算で解が得られない状況も確認できた。 以上 

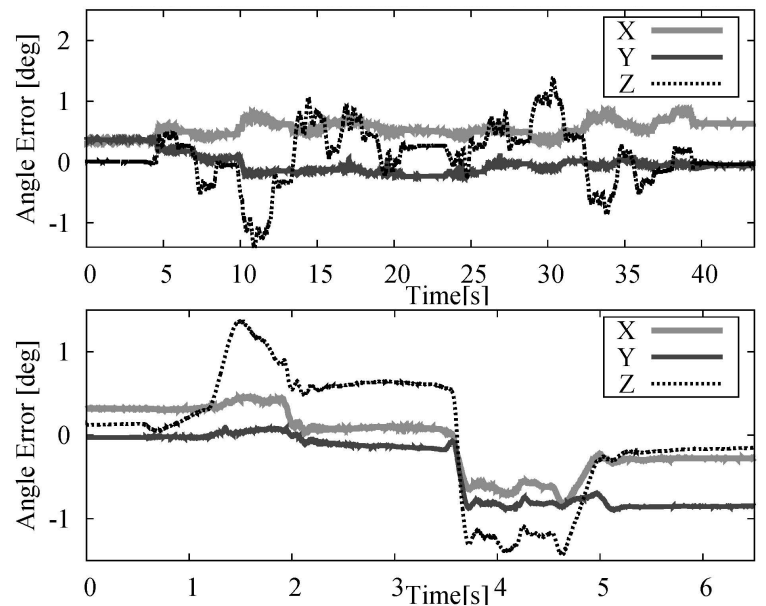

Fig. 18 Base-link angle tracking error on a real robot. Baselink angle around the $\mathrm{X}, \mathrm{Y}$, and $\mathrm{Z}$ axes. Vertical ladder climbing (upper graph) and transition from catwalk and ladder (bottom graph)

より，遊脚期にもキーフレームを設定することが制約を満たす だけでなく制約境界から余裕を持った解を得ることに寄与する ことが示された。

\section{6 実機への適用実験}

モデル化誤差など補償するセンサフィードバック制御 $[8]$ を伴 い, 計画軌道を実機上で再生した。制御系には, 軌道計画器か ら関節角, トルク, 接触レンチ, エンドエフェクタの軌道を目 標值として入力し, 接触レンチの計測值と目標值の誤差に応じ てエンドエフェクタ位置姿勢を修正する接触力制御, 体幹位置 姿勢推定に基づく着地位置補正を介して，最終的な関節角出力 を計算し関節サーボ系へ指令する．実機の挙動を示す状態量と して, Fig. 18 に垂直はしご昇り動作, キャットウォークから栈 への乗り移り動作に打ける腰姿勢追従誤差を示す. 追従誤差が 十分に小さく，ロボットが転倒せず三次元的な運動を実現して いることが分かる. 以上より, 提案手法により計画した軌道で 実機でのはしごタスクが実現可能であることが示された.

\section{7. 結 論}

本稿では, 重心実行可能領域を利用した粗密段階計算に基づ くヒューマノイドロボットの軌道計画法を提案した，具体的に は，局所座標系を活用することで動力学的な重心実行可能領域 が静力学的なものと同様に求まることを明らかにし, 線形計画 法に基づく重心実行可能領域への射影法を示した。これにより, 粗な運動計算（キーポーズ生成）に扒いても動力学を考慮した 重心実行可能領域を用いて運動学制約と動力学制約を同時に満 たす方法を提案した。 さらに, 支持脚期・遊脚期双方でキーフ レームを設定し漸近的に重心実行可能領域の制約を満たす逆運 動学を解くことで, 実行可能でかつ制約境界から余裕のあるキー ポーズ生成を行う方法を提案し, キーポーズ列からの誤差を最 小化する補間計算と瞬時全身運動計算を用いて最終的な軌道を 得る粗密段階計算法を示した。これにより, 運動学的な制約境 界からの余裕度が改善することを示し, またバランス制約が複 雑でかつ遊脚期・支持脚期で大きく変わるような乗り移り動作
のキーポーズ生成も可能になることを示した，垂直はしご昇降， 乗り移り，2 足，4 足歩行など, 制約の厳しく多様な軌道計画に 対し提案手法が統一的に適用可能であることを示し，実機にて これまで実現例が少ない垂直はしご昇り，実現例がない乗り移 り動作を実現可能であることを示した。

\section{参 考 文 献}

[1] H. Yoneda, K. Sekiyama, Y. Hasegawa and T. Fukuda: "Vertical ladder climbing motion with posture control for multilocomotion robot," Proc. of the 2008 IEEE/RSJ International Conference on Intelligent Robots and Systems, pp.3579-3584, 2008.

[ 2 ] J. Vaillant, A. Kheddar, H. Audren, F. Keith, S. Brossette, K. Kaneko, M. Morisawa, E. Yoshida and F. Kanehiro: "Vertical Ladder Climbing by the HRP-2 Humanoid Robot," Proc. of the 2014 IEEE-RAS International Conference on Humanoid Robots, pp.671-676, 2014.

[ 3 ] J. Luo, Y. Zhang, K. Hauser, H.A. Park, M. Paldhe, C.S.G. Lee, M. Grey, M. Stilman, J.H. Oh, J. Lee, I. Kim and P. Oh: "Robust Ladder-Climbing with a Humanoid Robot with Application to the DARPA Robotics Challenge," Proc. of the 2014 IEEE International Conference on Robotics and Automation, pp.2792-2798, 2014.

[4] S. Noda, M. Murooka, S. Nozawa, Y. Kakiuchi, K. Okada and M. Inaba: "Generating whole-body motion keep away from joint torque, contact force, contact moment limitations enabling steep climbing with a real humanoid robot," Proc. of the 2014 IEEE International Conference on Robotics and Automation, pp.1775-1781, 2014.

[ 5 ] 濱元伸也, 吉田雄貴, 橋本健二, 孫潚, 寺町知峰, 松澤貴司, 木村䭻介, 酒井伸明, 高西淳夫：“極限環境下で作業可能な災害対応ロボットの 開発（第 6 報：安定判別規範を用いた 2 点支持による垂直はしご昇降 の実現)", 第 34 回日本ロボット学会学術講演会予稿集 DVD-ROM, AC2C1-01, 2016.

[6] I. Mordatch, E. Todorov and Z. Popovic: "Discovery of Complex Behaviors through Contact-Invariant Optimization," Proc. of ACM SIGGRAPH 2012, vol.31, no.43, 2012.

[ 7 ] H. Dai, A. Valenzuela and R. Tedrake: "Whole-body motion planning with centroidal dynamics and full kinematics," Proc. of the 2014 IEEE-RAS International Conference on Humanoid Robots, pp.295-302, 2014.

[ 8 ] M. Kanazawa, S. Nozawa, Y. Kakiuchi, Y. Kanemoto, M. Kuroda, K. Okada, M. Inaba and T. Yoshiike: "Robust Vertical Ladder Climbing and Transitioning between Ladder and Catwalk for Humanoid Robots," Proc. of the 2015 IEEE/RSJ International Conference on Intelligent Robots and Systems, pp.2202-2209, 2015.

[ 9 ] H. Hirukawa, S. Hattori, K. Harada, S. Kajita, K. Kaneko, F. Kanehiro, K. Fujiwara and M. Morisawa: "A Universal Stability Criterion of the Foot Contact of Legged Robots - Adios ZMP," Proc. of the 2006 IEEE International Conference on Robotics and Automation, pp.1976-1983, 2006.

[10] 張暁毅, 中村仁彦, 吉本堅一：“不完全な接触をもつ把持の力学的多 面凸解析”, 日本ロボット学会誌, vol.14, no.1, pp.105-113, 1996.

[11] S. Caron and A. Kheddar: "Multi-contact Walking Pattern Generation based on Model Preview Control of 3D COM Accelerations," Proc. of the 2016 IEEE-RAS International Conference on Humanoid Robots, pp.550-557, 2016.

[12] Z. Qiu, A. Escande, A. Micaelli and T. Robert: "Human motions analysis and simulation based on a general criterion of stability," International Symposium on Digital Human Modeling, pp.1-8, 2011.

[13] S. Cotton, P. Fraisse and A.P. Murray: "On the Manipulability of the Center of Mass of Humanoid Robots: Application to Design", Proc. of the ASME 2010 International Design Engi- 
neering Technical Conferences and Computers and Information in Engineering Conference, pp.1259-1267, 2010.

[14] K. Harada, S. Kajita, K. Kaneko and H. Hirukawa: "ZMP Analysis for Arm/Leg Coordination," Proc. of the 2003 IEEE/ RSJ International Conference on Intelligent Robots and Systems, pp.75-81, 2003.

[15] S. Caron, Q.-C. Pham and Y. Nakamura: "ZMP support areas for multi-contact mobility under frictional constraints," CoRR, vol.abs/1510.03232, 2015.

[16] K. Harada, H. Hirukawa, F. Kanehiro, K. Fujiwara, K. Kaneko, S. Kajita and M. Nakamura: "Dynamical Balance of a Humanoid Robot Grasping an Environment," Proc. of the 2004 IEEE/RSJ International Conference on Intelligent Robots and Systems, pp.1167-1173, 2004.

[17] N. Naksuk and C.S.G. Lee: "Zero moment point manipulability ellipsoid," Proc. of the 2006 IEEE International Conference on Robotics and Automation, pp.1970-1975, 2006.

[18] T. Bretl and S. Lall: "A Fast and Adaptive Test of Static Equilibrium for Legged Robots," Proc. of the 2006 IEEE International Conference on Robotics and Automation, pp.1109-1116, 2006.

[19] A.D. Prete, S. Tonneau and N. Mansard: "Fast algorithms to test robust static equilibrium for legged robots," Proc. of the 2016 IEEE International Conference on Robotics and Automation, pp.1601-1607, 2016

[20] A. Bemporad, M. Morari, V. Dua and E.N. Pistikopoulos: "The explicit linear quadratic regulator for constrained systems," Automatica, vol.38, no.1, pp.3-20, 2002.

[21] K. Fukuda and A. Prodon: "Double description method revisited," Combinatorics and Computer Science, pp.91-111, 1996.

[22] K. Hauser, T. Bretl and J-C. Latombe: "Non-gaited Humanoid Locomotion Planning," Proc. of the 2005 IEEE-RAS International Conference on Humanoid Robots, pp.7-12, 2005.

[23] A. Escande, A. Kheddar and S. Miossec: "Planning support contact-points for humanoid robots and experiments on HRP2," Proc. of the 2006 IEEE/RSJ International Conference on Intelligent Robots and Systems, pp.2974-2979, 2006.

[24] J. Carpentier, S. Tonneau, M. Naveau, O. Stasse and N. Mansard: "A Versatile and Efficient Pattern Generator for Generalized Legged Locomotion," Proc. of the 2016 IEEE International Conference on Robotics and Automation, pp.35553561,2016

[25] K. Bouyarmane, J. Vaillant, F. Keith and A. Kheddar: "Exploring Humanoid Robots Locomotion Capabilities in Virtual Disaster Response Scenarios," Proc. of the 2012 IEEE-RAS International Conference on Humanoid Robots, pp.337-342, 2012.

[26] T. Nishi and T. Sugihara: "Motion Planning of a Humanoid Robot in a Complex Environment Using RRT and Spatiotemporal Post-Processing Techniques," International Journal of Humanoid Robotics, vol.11, no.2, pp.1-35, 2014.

[27] K. Harada, S. Hattori, H. Hirukawa, M. Morisawa, S. Kajita and E. Yoshida: "Two-Stage Time-Parametrized Gait Planning for Humanoid Robots," IEEE/ASME Transaction on Mechatronics, vol.14, no.5, pp.694-703, 2010.

[28] K. Harada, M. Morisawa, S. Nakaoka, K. Kaneko and S. Kajita: "Kinodynamic Planning for Humanoid Robots walking on Uneven Terrain," Journal of Robotics and Mechatronics, vol.21, no.3, pp.311-316, 2009

[29] K. Hauser: "Fast interpolation and time-optimization with contact," The International Journal of Robotics Research, vol.33, no.9, pp.12310-1250, 2014.

[30] 布川吴, 中山弘隆, 谷野哲三 : 現代応用数学講座 8 線形代数と凸解 析. コロナ社, 1991 .

[31] S. Kajita, F. Kanehiro, K. Kaneko, K. Fujiwara, K. Harada, K. Yokoi and H. Hirukawa: "Biped walking pattern generation by using preview control of zero-moment point," Proc. of the 2003
IEEE International Conference on Robotics and Automation, pp.1620-1626, 2003.

[32] 竹中透, 松本隆志, 吉池孝英：“床反力限界を考慮した 2 脚ロボットの 実時間動力学補償”, 日本ロボット学会誌, vol.32, no.3, pp.295-306, 2014.

[33] T. Kamioka, T. Watabe, M. Kanazawa and H. Kaneko: "Dynamic gait transition between bipedal and quadrupedal locomotion," Proc. of the 2015 IEEE/RSJ International Conference on Intelligent Robots and Systems, pp.2195-2201, 2015.

[34] F. Kanehiro, M. Morisawa, W. Suleiman, K. Kaneko and E. Yoshida: "Integrating geometric constraints into reactive leg motion generation," Proc. of the 2010 IEEE/RSJ International Conference on Intelligent Robots and Systems, pp.4069-4076, 2010.

[35] 長阪憲一郎, 福島哲治, 下村秀樹：“接触拘束を考慮可能なマルチコン タクト対応スタビライザと一般化逆動力学による人型ロボットの全身 制御”，第 17 回ロボティクスシンポジア予稿集，pp.134-141, 2012.

[36] A. Herdt, H. Diedam and P. Wieber: "Online walking motion generation with automatic foot step placement," Advanced Robotics, vol.24, no.5-6, pp.719-737, 2010.

\section{付録 A. 接触制約と力学平衡式}

式（1）は次のようにして得られる。

$$
\begin{gathered}
\boldsymbol{C}=\text { quasidiag }\left({ }^{0} \boldsymbol{C}_{0} \boldsymbol{R}_{0,6}^{T}, \ldots, \quad{ }^{N_{L}-1} \boldsymbol{C}_{N_{L}-1} \boldsymbol{R}_{N_{L}-1,6}^{T}\right) \\
\boldsymbol{R}_{j, 6}=\text { blockdiag }\left(\boldsymbol{R}_{j}, \boldsymbol{R}_{j}\right) \\
\boldsymbol{b}=\left[\begin{array}{cccc}
\boldsymbol{b}_{0}^{T} \ldots \boldsymbol{b}_{N_{L}-1}^{T} & ]^{T}, & \boldsymbol{w}=\left[\boldsymbol{w}_{0}^{T} \ldots \boldsymbol{w}_{N_{L}-1}^{T}\right.
\end{array}\right]^{T} \\
\boldsymbol{G}=\left[\begin{array}{ccccc}
\boldsymbol{E}_{3} & \mathbf{0} & \ldots & \boldsymbol{E}_{3} & \mathbf{0} \\
\boldsymbol{p}_{0} \times & \boldsymbol{E}_{3} & \cdots & \boldsymbol{p}_{N_{L}-1} \times & \boldsymbol{E}_{3}
\end{array}\right]
\end{gathered}
$$

接触座標系を足先・手先といった各接触部位に設定する座標系と L, $\boldsymbol{p}_{j}=\left[\begin{array}{lll}p_{j x} & p_{j y} & p_{j z}\end{array}\right]^{T}$ は第 $j$ 接触座標系の原点位置, $\boldsymbol{R}_{j}$ は 姿勢, $\boldsymbol{w}_{j}=\left[\begin{array}{llllll}f_{x} & f_{y} & f_{z} & n_{x} & n_{y} & n_{z}\end{array}\right]_{j}^{T}$ は接触レンチであり，それ ぞれ絶対座標系表記とする。 ${ }^{j} \boldsymbol{C}_{j}$ は第 $j$ 接触部位に関する接触 座標系相対の接触制約行列， $\boldsymbol{b}_{j}$ は接触制約ベクトルである（付 録 B). blockdiag は正方行列のブロック対角行列, quasidiag は必ずしも正方でない行列を対角に並べた行列を示す.

\section{付録 B． 接触制約計算法}

各接触部位独立に設定する接触制約は，圧力中心制約，摩擦制 約，上下限制約により定義する。接触制約は，接触面を多角形， 摩擦円錐を多角すいとすることで線形不等式として計算する。 本制約計算法では，ハンドの接触も巨視的に表現可能である。

接触部位で面接触（線接触も同様）しており，法線方向が Z, $\mathrm{XY}$ 軸が面内に含まれるとする。 凸多角形の接触面に圧力中心 が含まれる制約は次になる。

$$
\left[\begin{array}{llllll}
0 & 0 & \left(d_{y}^{i} x_{l}^{i}-d_{x}^{i} y_{l}^{i}\right) & d_{x}^{i} & d_{y}^{i} & 0
\end{array}\right] \boldsymbol{w}_{j} \geq 0
$$

これは多角形の第 $i$ 辺の不等式であり, $x_{l}^{i}, y_{l}^{i}$ は多角形が通る 点, $d_{x}^{i}, d_{y}^{i}$ は辺の方向ベクトルである. これらは接触面の辺長 さなどにより決定される.

摩擦円すいを凸多角すいで近似したとき，力ベクトルが摩擦 凸多角すいに含まれる並進摩擦制約も同様に次のようになる.

$$
\left[\begin{array}{llllll}
-d_{y}^{i} & d_{x}^{i} & \left(d_{y}^{i} p_{x}^{i}-d_{x}^{i} p_{y}^{i}\right) & 0 & 0 & 0
\end{array}\right] \boldsymbol{w}_{j} \geq 0
$$



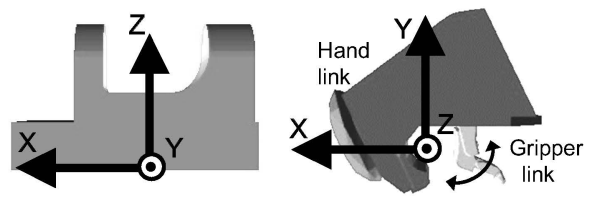

Fig. 19 Definitions of frames of foot and hand

$d_{x}^{i}, d_{y}^{i}$ は凸多角すいの $f_{z}=1$ 断面の凸多角形の第 $i$ 辺方向べ クトルであり, $p_{x}^{i}, p_{y}^{i}$ は辺が通る点である.これらは摩擦係数 などより決定される.

力・モーメントの上下限も同様に定義できる.

$$
\left[\begin{array}{cccccc}
0 & 0 & 1 & 0 & 0 & 0 \\
0 & 0 & -1 & 0 & 0 & 0
\end{array}\right] \boldsymbol{w}_{i} \geq\left[\begin{array}{c}
f_{z}^{-} \\
-f_{z}^{+}
\end{array}\right]
$$

上記は $f_{z}$ の例であり, $f_{z}^{-}=0$ の場合は反力の非負制約に相当す る.上下限制約により凸多面すい $[9]$ にみられる過大な接触レン チを防げるほか，有界な凸多角形が CFR として得ることができ， 明らかに運動学的に実行可能でない領域を省くことができる.

回転摩擦も係数を $\mu_{r}$ とし次を得る.

$$
\left[\begin{array}{cccccc}
0 & 0 & \mu_{r} & 0 & 0 & -1 \\
0 & 0 & \mu_{r} & 0 & 0 & 1
\end{array}\right] \boldsymbol{w}_{j} \geq \mathbf{0}
$$

足裏面接地の例を示す. Fig. 19 左図は足先形状および足先 座標系である。接触制約 ${ }^{j} \boldsymbol{C}_{j}, \boldsymbol{b}_{j}$ は, XY 軸並進摩擦, Z 軸回 り回転摩擦, $\mathrm{XY}$ 面接触の圧力中心, $Z$ 軸の力の非負·上限の制 約で定義した，摩擦すいは四角すい，面は長方形とした。過大な 力を防ぐため, $Z$ 軸の力にも上限值を設定した. 足裏栈接地時 には足裏が線接触となるように設定した，手先であっても 4 足 歩行のように面接地をする場合は足裏接触制約と同様に扱った.

手先接触の例を示す. Fig. 19 右図は手先形状および手先座 標系である，座標系は，手先方向が $X$, 把持軸方向が $Z$ であ る. 本稿で扱ったロボットの手先は, かぎ爪状のリンク ("Hand link"）と親指リンク（"Gripper link"）とからなる. かぎ爪部 と親指リンクで栈などを把持できるよう 1 自由度のグリッパ関 節を有する。手先のかぎ爪部の非線形な摩擦拘束は線形化して 制約を定義した。 また，例えばはしご栈把持時には，栈を手先 のかぎ爪が機構的に包み込むため, 理想的には無限大の $Y$ 軸 の力および $X$ 軸回りモーメントを発生できる.ねじり, 変形, およびグリッパの最大把持トルクなどの原因で, 実際には無限 に力・モーメントを発生させることはできないため，上下限を 設定することとした. 以上より, 接触制約 ${ }^{j} \boldsymbol{C}_{j}, \boldsymbol{b}_{j}$ は, $Z$ 軸 並進摩擦, $Z$ 軸回り回転摩擦, $Z$ 軸圧力中心, $X$ 軸の力の非 負 ·上限 $(800[\mathrm{~N}]), Y$ 軸の力の上下限 $( \pm 70[\mathrm{~N}]), X$ 軸回り モーメントの上下限 $( \pm 5[\mathrm{Nm}])$ の制約で定義した.

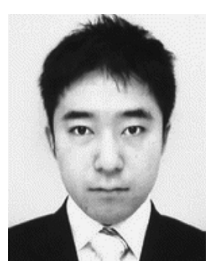

\section{野沢峻一（Shunichi Nozawa)}

2013 年東京大学情報理工学系研究科知能機械情報 学専攻博士課程修了. 博士 (情報理工学). 2013 年 同大学助教, 2016 年特任講師となり現在に至る. 2010 年から 2013 年まで日本学術振興会特別研究 員. ヒューマノイドロボットによる全身物体操作の 研究に従事.

(日本ロボット学会正会員)

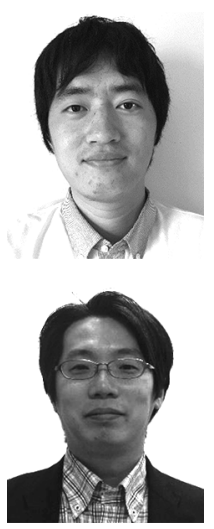

金澤雅夫（Masao Kanazawa）

2009 年東京工業大学大学院修士課程修了（機械制 御システム専攻)。2009 年より (株) 本田技術研究 所 基礎技術研究センター一般研究員. ヒューマ) イドロボットの運動生成・制御などの研究に従事.

\section{垣内洋平 (Yohei Kakiuchi)}

1998 年東京大学工学部機械情報工学科卒業. 2000 年東京大学工学系研究科機械情報工学専攻修士課程 修了. 同年三菱重工業（株）入社. 2012 年東京大 学情報理工学系研究科知能機械情報学専攻博士課程 修了. 博士 (情報理工学). 2012 年同大学特任助教, 2014 年特任講師となり現在に至る. ヒューマノイ ドロボットによる家事支援, 三次元点群処理の研究に従事.

（日本ロボット学会正会員）

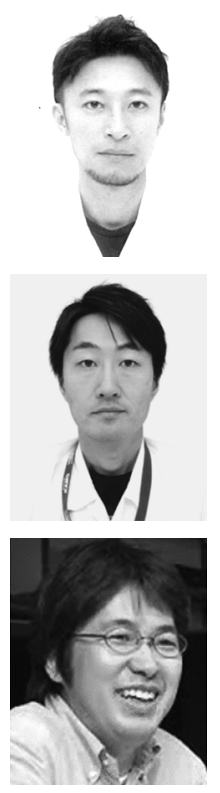

金本良樹（Yoshiki Kanemoto）

2007 年東京大学大学院工学系研究科システム量子工 学専攻修士課程修了. 同年から 2017 年にかけ, (株) 本田技術研究所基礎技術研究センターにてヒューマ ノイドロボットの動作生成・制御などの研究開発に 従事.

黒田貢秀 (Mitsuhide Kuroda)

1999 年芝浦工業大学 電子工学科卒業. 1999 年上 り (株) 本田技術研究所基礎技術研究センター研究 員. 交通シミュレータなどの開発を経て，ヒューマ ノイドロボットの運動制御などの研究に従事.

\section{岡田 慧（Kei Okada）}

1997 年京都大学工学部情報工学科卒業. 2002 年 東京大学大学院工学系研究科情報工学専攻博士課 程修了. 博士 (工学). 2002 年東京大学大学院情 報理工学系研究科科学技術振興特任教員. 2006 年 同特任講師. 2009 年同大学准教授となり現在に至 る. ヒューマノイド統合システム, ヒューマノイド プランナ, 実時間三次元ビジョンの研究に従事. 1999 年第 4 回ロボ ティクスシンポジア優秀論文賞，2006 年 IEEE-RAS International Conference on Humanoid Robots Best Paper Award 受賞. 情報 処理学会, IEEE の各会員.

（日本ロボット学会正会員）

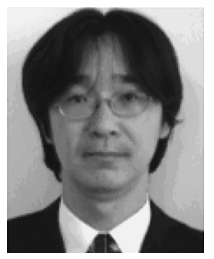

吉池孝英 (Takahide Yoshiike)

1998 年東京大学大学院修士課程修了（機械情報工学 専攻). 1998 年より (株) 本田技術研究所基礎技術 研究センター研究員. 2009 年より Honda Research Institute Europe GmbH にて Principal Scientist. 2012 年より (株) 本田技術研究所基礎技術研究七 ンター主任研究員. 2017 年より Honda Research Institute Japan にて Principal Researcher. ヒューマノイドロボッ トの運動生成の研究に従事.

（日本ロボット学会正会員）

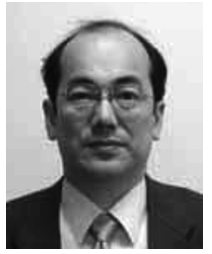

稲葉雅幸（Masayuki Inaba）

1981 年東京大学工学部機械工学科卒業. 1986 年東 京大学大学院情報工学専門課程博士課程修了 (工学 博士). 1986 年東京大学講師, 助教授を経て，2000 年教授. 現在東京大学大学院情報理工学系研究科創 造情報学専攻所属. 知能ロボットシステムの研究教 育に従事. 日本機械学会, 計測自動制御学会, 情報 処理学会, 人工知能学会, ソフトウェア科学会等会員.

（日本ロボット学会正会員） 